برنامج مقترح لتنمية الإبتكار في الموسيقى العربية عند الطالب المتخصص

"The Effectiveness of the Proposed Program for the Development of Innovation in Arab Music Specialist for the Student"

$$
\text { بعثث مقدم من }
$$

إستكمالاً للحصول على درجة الماجستير في التربية النوعية

تخصص تربية موسيقية شعبة (تأليف الموسيقي العربية) 


\section{ملخص الار اسةة}

بما أنتا نساير الأففية الثالثة وهو عصر التكنولوجيا الذي يثجع علي الابتكــار فــي كافــة

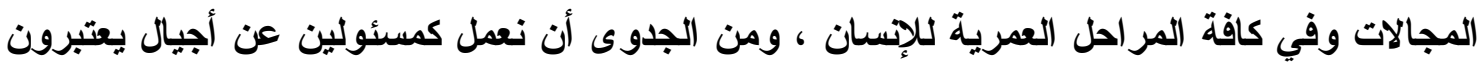
بدورهم شباب الغد بتنمية الإبتكار لايهم حيث أن طلاب كلية التربة النوعية شعبة التربية الموسيقية يلتحقون بالكلية بعد أدائهم امتحان القدرات يقس مدى قاراتهم وتذوقهم الموسيقي كما تعتمد الكلية على الأداء الآلي اى ان طلاب الكلية يقاسوا بالقدرة الفطرية ولكنهم لا يستطيعون الإبتكــار. لـــلكك

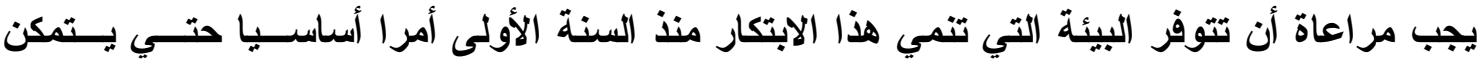

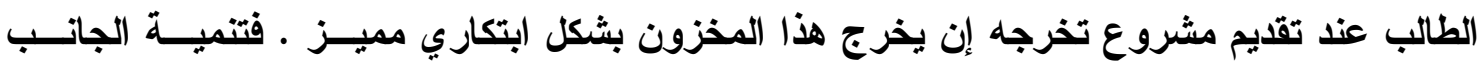
الابتكاري يفضل أن تبدأ من الصغر عن طريق تثجيع التفكير الناقد والملاحظة وحرية التعبير وتقبل الاختلاف وتستمر عملية التنمية منذ دخول الطالب في الحياة الدراسية حتي يخرج إلى الحياة العملية و واثقا في امكاناته مدركا لافكارة جريئا في تنفيذها ــ ويتأثر الناتج الابتكاري بمجموعة من العوامـل

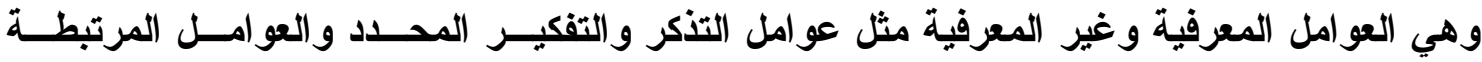
بالتقويم أي عوامل الذكاء ، وعوامل تؤدي للناتج الجيد والإتتاج الجيد من الفكر أو الفن أو الأدب أو الو الفي العلم مثل الحساسية للمشكلات و إدراك الفجوات ومواطن الضعف والخطأ فيما لاينا من معلومسـات ، ومنها عو امل الطلاقة والمرونة والأصالة وتحتاج للثقة في النفس والاعتماد على النفس والاكتفــاء الأتي و السيطرة ، و العو امل المرتبطة بالإنتاج الابتكاري من السمات الاففعالية و العوامل العقلية التي

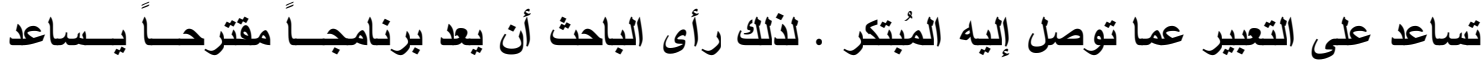

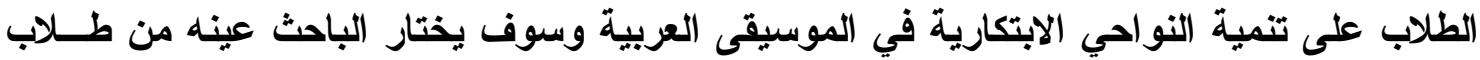

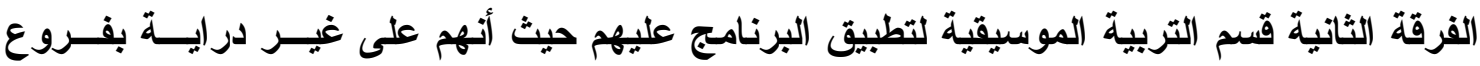
التربية الموسيقية عامة والموسيقى العربية خاصة لأنهم سوف يكونون مجرد مادة خام لا تحتــوي إلاّ على القدرات الموسيقية التي منحها الله لهم بنسب مختلفة وليست لديهم أي خبرة موسيقية تؤثر لائر

$$
\begin{aligned}
& \text { على مسار التجربة . } \\
& \text { مشكلة البحث : }
\end{aligned}
$$

بالرغم من أن بعض الطلاب منحهم الله الموهبة الموسيقية الفطرية بنـسب متفاوتــة تبعـاً

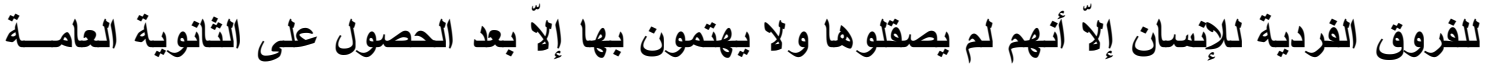

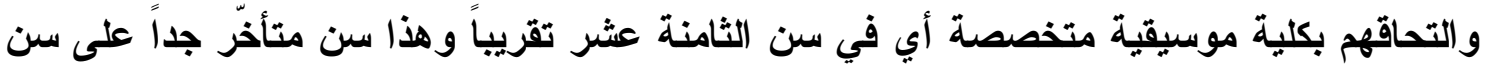

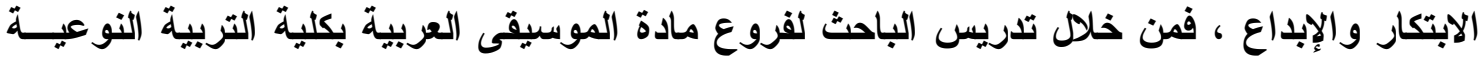

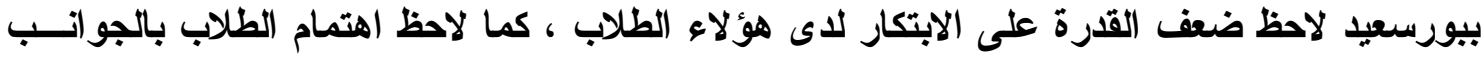

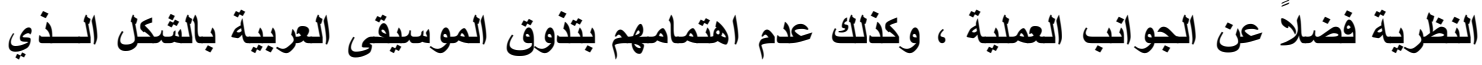
يساعدهم على تفهّم فروع المادة .

مجلة كلية التربية - جامعة بورسعيد ك111

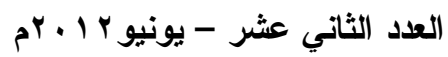




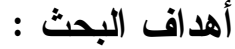

ا ـ قياس الموهبة الموسيقية الفطرية لدى طلاب الفرقة الأولى بكلية التربية النوعيسة جامعسة

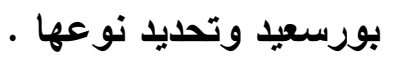

r. إعداد برنامج تطليمي يهذف إلى تنمية المهارات الأبتكاريــة لـــى الطـلاب المتخصـصـين بخوات مرتبة حتى يتمكن الطلاب على ابتكار الأحلان .

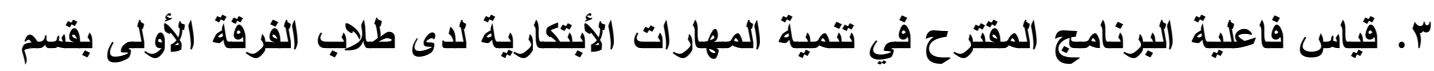

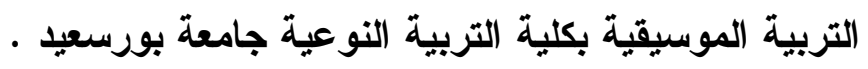

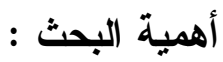

إعداد خريج متخصص قادر على الابتكار في الموسيقي العربية مما يعود عليه بـالنفع فـي لئ

حياته المهنية والعملية وعند تدريسه للأطفال .

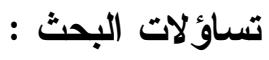

1. ما مستوى القدرات الموسيقية لاى طلاب التربية الموسيقية المتو اجدة بنسب متفاوتة ؟.

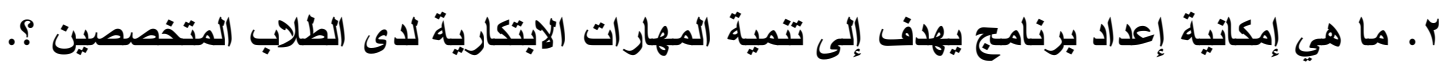

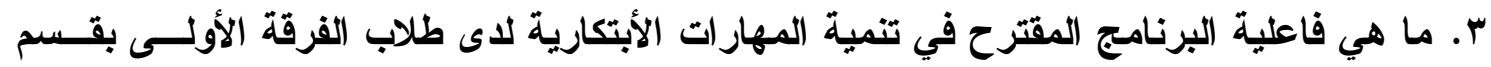
التربية الموسيقية بكلية التربية النوعية ؟.

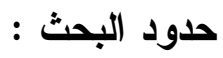

• دود مكانية: الفرقة الأولى بقسم التربية الموسيقية كليــة التربيــة النوعيــة جامعـة

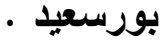

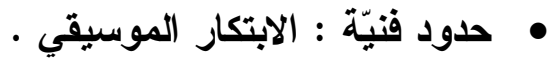

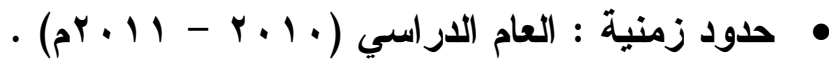

$$
\begin{aligned}
& \text { إجراءات البحث : - إن } \\
& \text { • أولاً: منهج البحث : المنهج الوصفي (تحليل محتوى). }
\end{aligned}
$$

• • ثانياً: عينة البحث : طلاب الفرقة الأولى بقسم التربية الموسيقية.

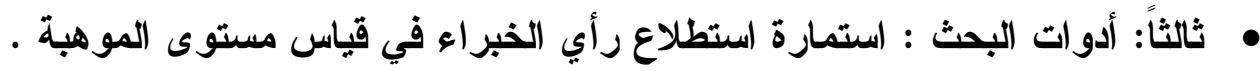

مصطلحات البحث ، والدراسات السابقة للبحث .

$$
\text { الجزء النظري : }
$$

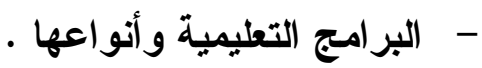

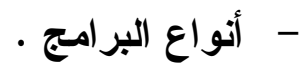

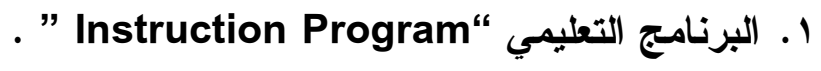

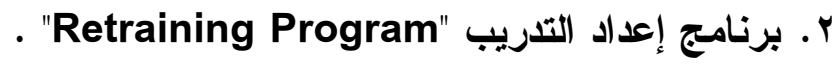

مجلة كلية التربية - جامعة بورسعيد >Y

العدد الثاني عشر - يونيو r I +rم 
r. "البرنامج المكثف "Intensive Program"

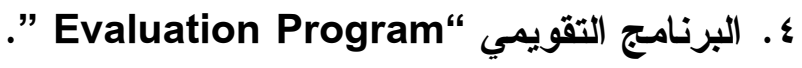
- - الابتكار ، ثم مفاهيم مرتبطة بمفهوم الابتكار الجزء التحليلي : وفيه عرض البحث بعض الحصص كنموذج استرشادي لتنفيذ البرنامج المقتـرح الذي يعمل على تنمية الابتكار عند الطلاب في الموسيقى العربية . نتائج البحث :

1 - التركيز علي تذوق مقام واحد خلال الفصل الدراسي الواحد يساعد على تفهّمْ الطــلاب

وتنمية النواحي الابتكارية في الموسيقي العربية لايهم .

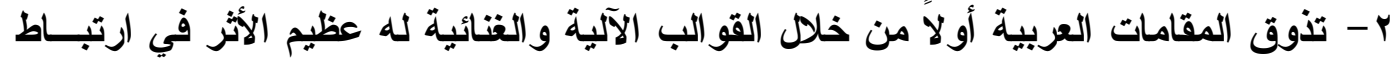

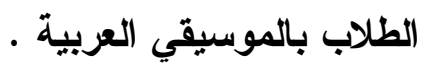

ب- تقديم الجواتب النظرية للمقامات العربية في مرحلة تلي تذوق المقام غنائياً وآلياً يسـاعد

$$
\begin{aligned}
& \text { على تفهم المقام نظرياً . } \\
& \text { توصيات البحث: يوصي الباحث بما يلي : }
\end{aligned}
$$

أ) وضع الابتكار في الموسيقي العربية ضمن بنود مقرر الموسـيقي العربيـة فــي الكليـات

ب) الاهتمام بطلاب الفرقة الأولى وإعدادهم فنياً حيث أنهم نواه معلمي الغد . ج) الاهتمام بالمحتوي التعليمي المقدم للطلاب على أن يحتوي علي التذوق الموسيقي أكثر مـن

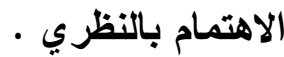

المقدمة

المجتمع له دوراً كبير الأثر في نثأة وتكوين حياته الإسـانية من أسلاليب الفــرح والحــن

و الحكم على الأمور الحياتية العامة بالإضافة إلي تثكيل وتكوين مزاجه القنـــ ـ توضـيح عمليــة الإبداع الفني في الواقع هي تعبير عقلي قائم علي مضمون وأحاسيس يرتفع بهم الــي الروحانيــة و الابداع الفني وهو ايضا صناعه انسانية تقدم للبشريه ماده جماليه بغرض اسعادها ومسـن ناحيـهـ آخري فالفنون هي المثثقف الأول للثعوب علي نطاقها العريض، لأهها ليست موجه الي فئه صــيرة

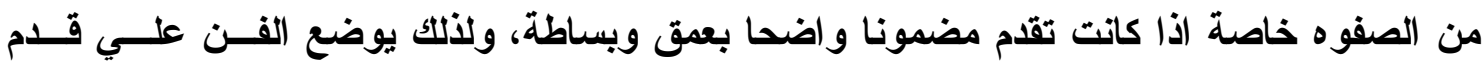
المساواة مع القلسفة فكلاهما يخضع لمفعول العقل وكلاهما يتطور مع الزمن وكلاهما مسن وســائل المعرفه ولذلك لا يجب ان تعتبر الموسيقي نوع من انواع الطرف يهدف الي اللهو والتسليه. ويمسا

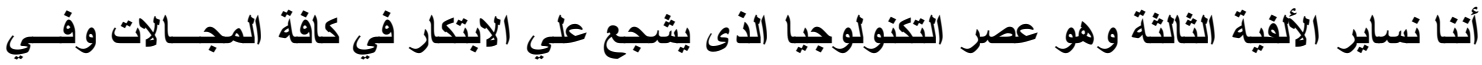
كافة المراحل العمرية للاسان ، ومن الجدوى أن نعمل كمسئولين عن أجيال يعتبرون بدورهم شباب

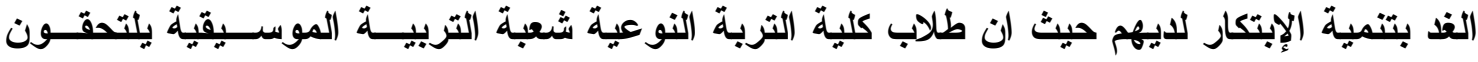




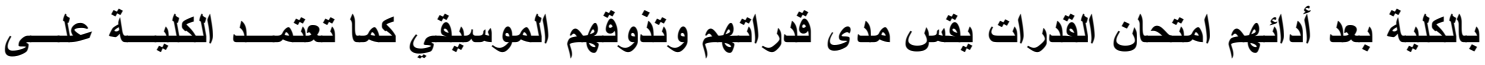

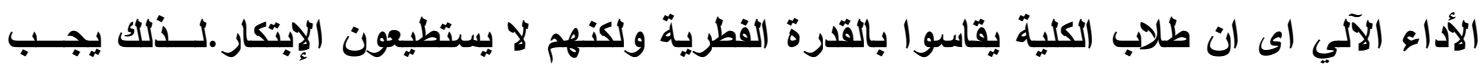

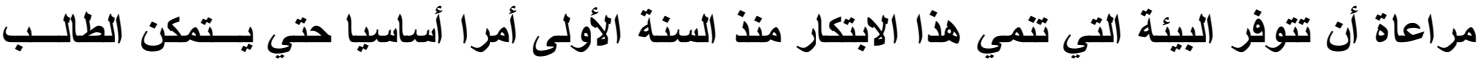

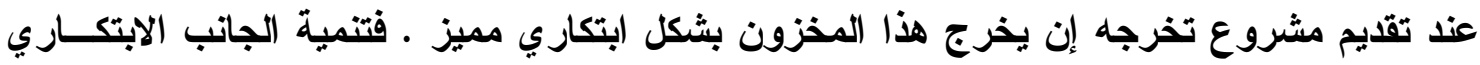
يفضل أن تبدأ من الصغر عن طريق تثجيع التفكير الناقد والملاحظة وحرية التعبير وتقبل الاختلاف وتستمر عملية التمية منذ دخول الطالب في الحياة الدراسية حتي يخرج إلي الحياة العملية واثقا في

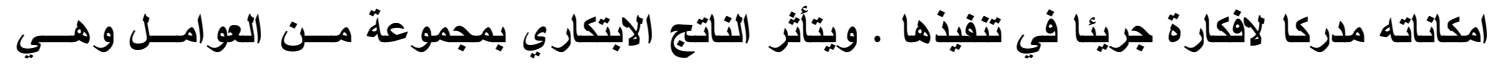

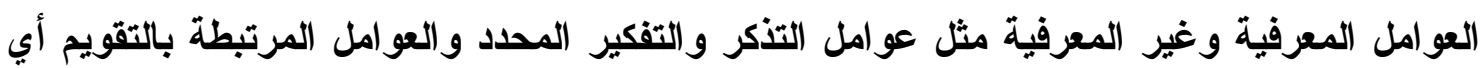
عوامل الذكاء ، وعوامل تؤدي للناتج الجيد والإنتاج الجيد من الفكر أو الفن أو الأدب أو العلم مثـلـل

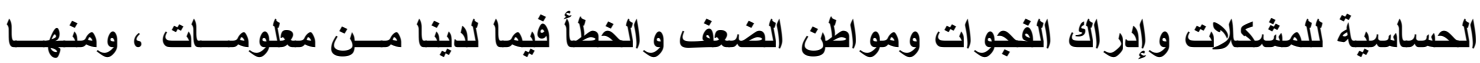
عوامل الطلاقة و المرونة والأصالة وتحتاج للثقة في النفس والاعتماد على النفس والاكتفاء الـــاتي و السيطرة ، والعوامل المرتبطة بالإتـاج الابتكاري من السمات الاتفعالية والعوامـلـل العقليــة التــي تساعد على التعبير عما توصل إليه المُبتكر . والتفكير الابتكاري يتميز بوجود عداد مـن التنظيمسات

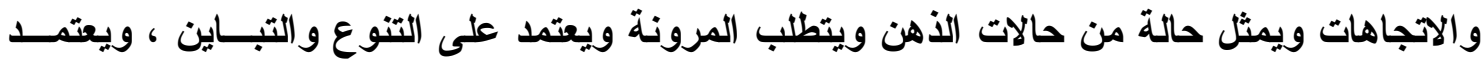

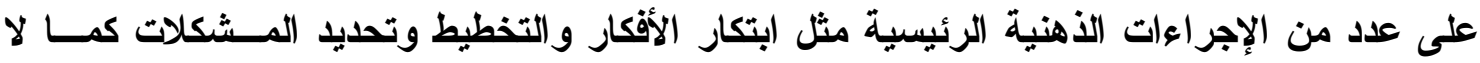

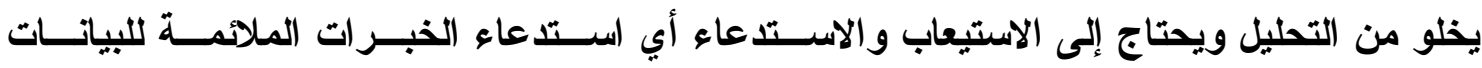

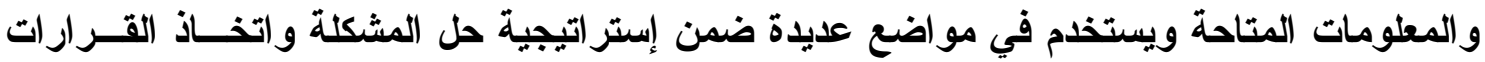
وتكوين المفاهيم ، فالتفكير في البدائل المتاحة ذاتها كغيرها من المنتجات الأخرى للتركيب الابتكاري

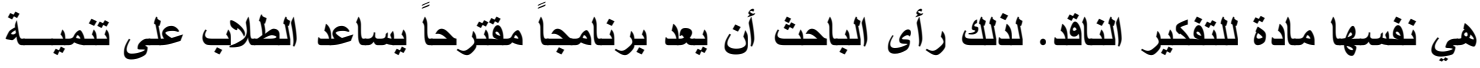

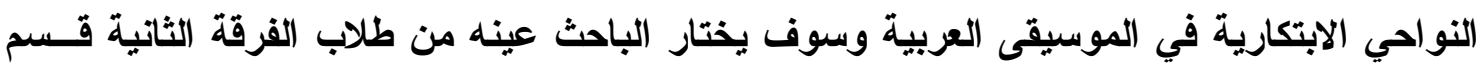
التربية الموسيقية لتطبيق البرنامج عليهم حيث أنهم على غير دراية بفروع التربية الموسيقية عامة فئه

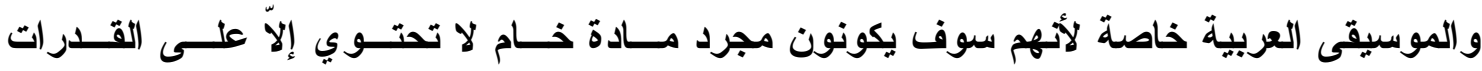
الموسيقية التي منحها الله لهم بنسب مختلفة وليست لايهم أي خبرة موسيقية تـؤيثر علـى مسكسار التجربة .

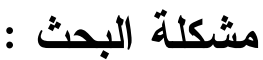
بالرغم من أن بعض الطلاب منحهم الله الموهبة الموسيقية الفطرية بنسب متفاوتة تبعاً للفروق

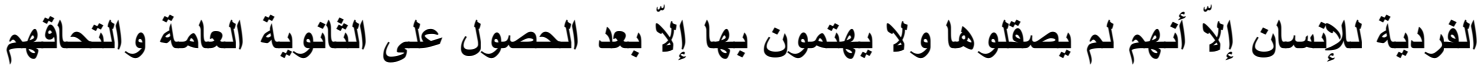
بكلية موسيقية متخصصة أي في سن الثامنة عشر تقريباً وهذا سن متأخرّ جداً على سـن الابتكـار

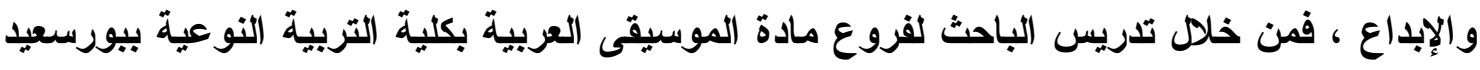

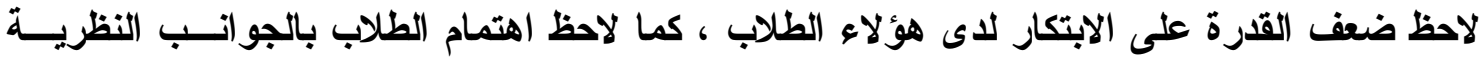


فضلاً عن الجوانب العملية ، وكذلك عدم اهتمامهم بتذوق الموسيقى العربية بالثكل الذي يـسـاعدهم

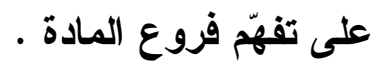

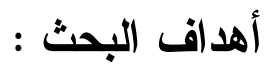

ا. قياس الموهبة الموسيقية الفطرية لدى طلاب الفرقة الأولى بكليـة التربيــة النوعيـة جامعـة

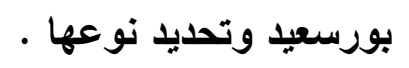

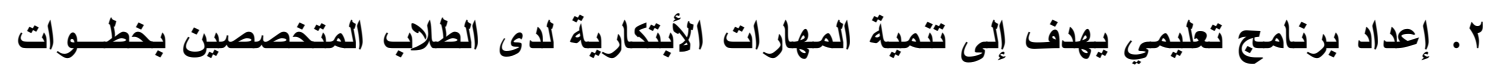

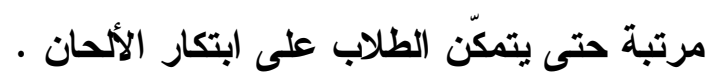

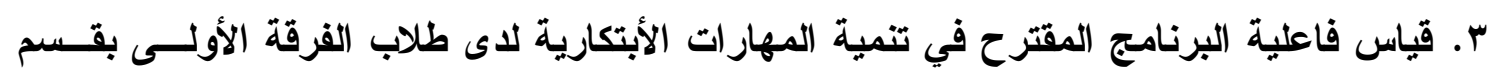

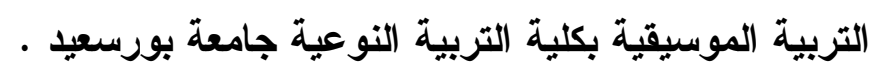
أهمبة البحث :

إعداد خريج متخصص قادر على الابتكار في الموسيقي العربية مما يعود عليه بالنفع في حياته

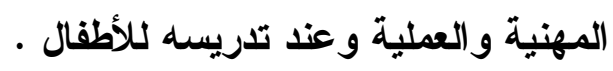

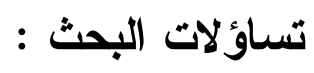

1. ما مستوى القدرات الموسيقية لاى طلاب التربية الموسيقية المتو اجدة بنسب متفاوتة ؟.

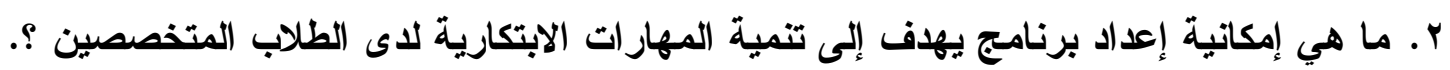

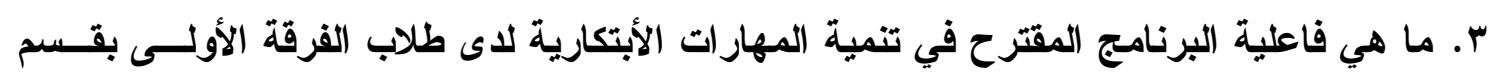
التربية الموسيقية بكلية التربية النوعية ؟. حدود البحث :

• حدود مكاتية: الفرقة الأولى بقسم التربية الموسيقية كليــة التربيــة النوعيـة جامعـة

$$
\begin{aligned}
& \text { بورسعيد . } \\
& \text { • حدود فنيّة : الابتكار الموسيقي . }
\end{aligned}
$$

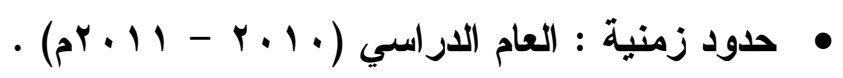

$$
\begin{aligned}
& \text { إجراعات البحث : } \\
& \text { • أولاً: منهج البحث : المنهج الوصفي (تحليل محتوى). }
\end{aligned}
$$

• ثانياً: عينة البحث : طلاب الفرقة الأولى بقسم التربية الموسيقية بكلية التربية النوعيــة

$$
\text { • ب ثبورسعيدا: أدوات البحث : }
$$

( ) استمارة استطلاع رأي الخبراء في قياس مستوى الموهبة .

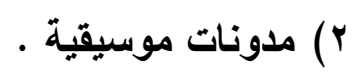


• آسجيلات سمعية وبصرية للبرنامج

مصطلحات البحث :

: Invitation الابتكار •

القدرة على أنتاج عدد كبير من الأفكر الأصلية غير العادية ودرجة عاليــة مـن المرونــة و الأستجابة وتطوير الأفكار والأنثطة.

• • • إستر اتيجية Strategy

هي جميع الإجراءات المحددة سابقاً التي يتبعها المعلم بغرض تحقيق أهـــاف تعليميــة معينــة و الوصول إلى مخرجات تعليم محددة ، وهذا يعني التخطيط الثامل لكيفية تنفيذ العمليـة التعليميـة

وتقويمها.

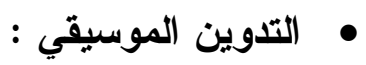

هو وسيلة نقل الألحان والإيقاعات من مكان لآخر ومن جيل لآخر فضلاً عن تخزينهــا بمس اكسا يحقى تراكم المعرفة الموسيقية ، ويؤدي إلى إحداث تطور كمي وكيفي في مجالاتها المختلفة.

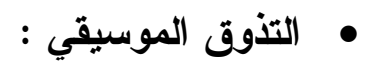

هو فهم الموسيقى و إدراكها عن طريق الإحساس بالقيمة الجمالية لهــا ـ وهـــا الإحسساس

يتضمن شقين بالنسبة للمستمع :

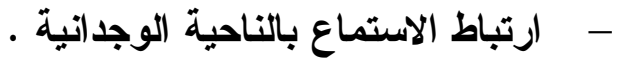

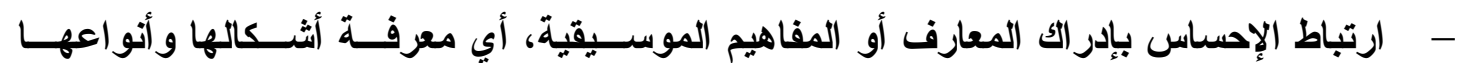

و أنماطها وتاريخها وآدابها للتعرف على روح وملامح ومميزات كل نوعية .

الار اسات السابقة للبحث :

() الدراسة الأولى بعنوان : " برنامج مقترح لتنمية الإبتكارية في مادة الصولفيج لطلاب كلية

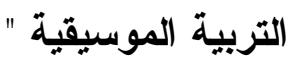

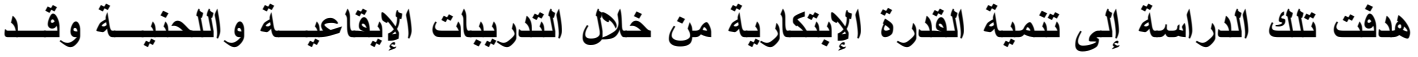
استخدت الباحثة المنهج التجريبي وكاتت عينة البحث من طلبة وطالبات الفرقة الأولى من طـلاب الابله الكلية وكان عددها ـ ـ طالب وطالبة حيث قسمت إلى مجموعتين تجريبية وضابطة وقــــ أســفرت

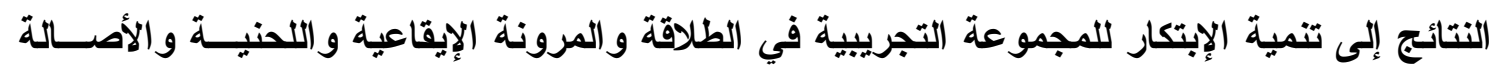
اللحنية ، بينما لم يحدث تغير بين المجموعتين في جاتب الأصالة الإيقاعية

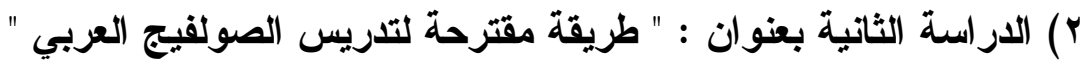
هافت تلك الدراسة إلى إيجاد طريقة غناء المقامات العربية عن طريق ربط العلاقة بينهم لارجة

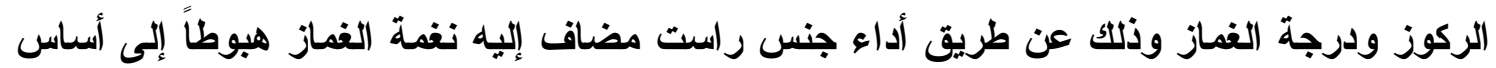


درجة الراست مع إستخلام نغمة السيكا، وكذلك أدائه مرة أخرى باستخدام درجة الحجاز بــلا مسن درجة الجهاركاه ، وبذلك يكون قد أدى الطالب جنس راست وجنس نهاوند وعقد نوأثر .

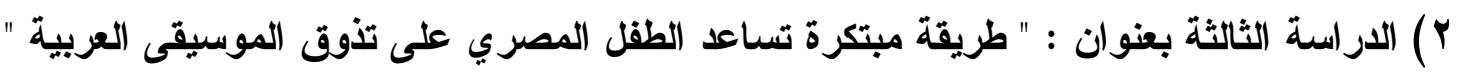

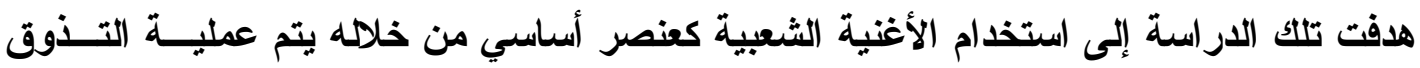
حيث تختلف هذه الاراسة مع الدراسة الحالية في إنها إستخدمت المنهج الوصفي (تحليل المحتوى)

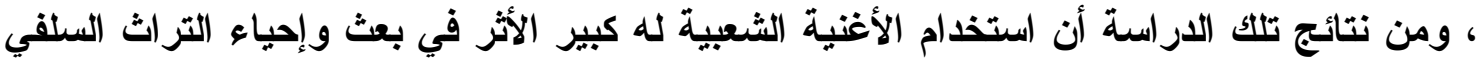

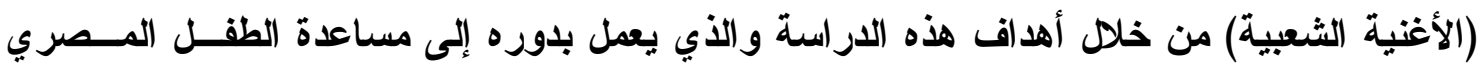
على تذوق الموسيقى العربية .

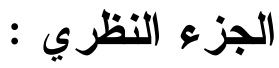
• البرامج التعليمية وأنواعها : يُعد تصميم البرامج التعليمية أحد أهم خطوات البناء التعليمي الحديث في شتى مجالات التعليم و التعلّم .

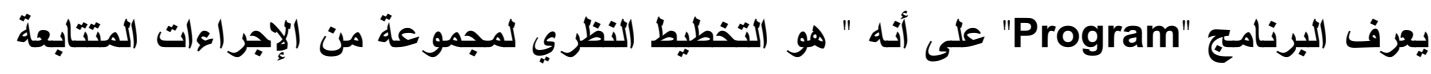
، تتضمن الجوانب المعرفية والمهارية والاتجاهات ". وللبرنامج تعريف آخر هو " المخطـط العسام

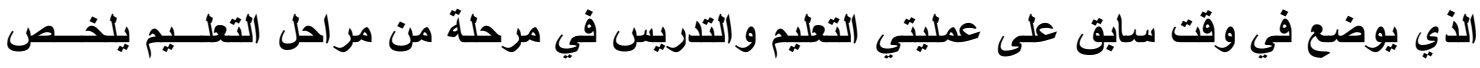

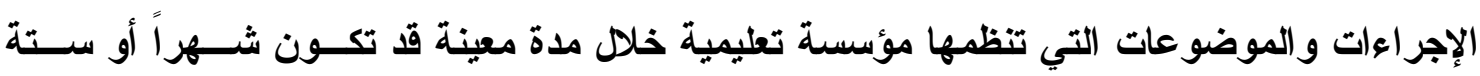

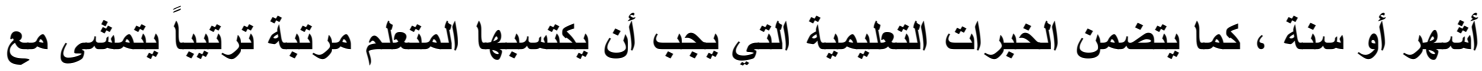

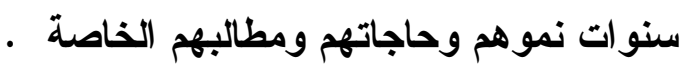

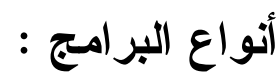

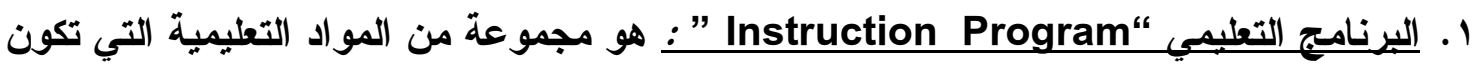

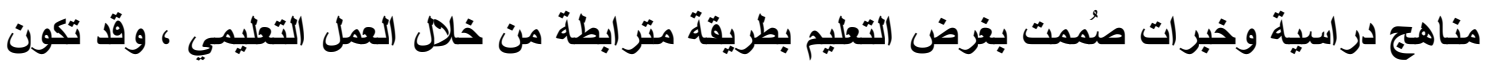

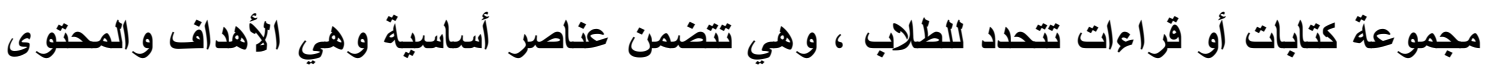

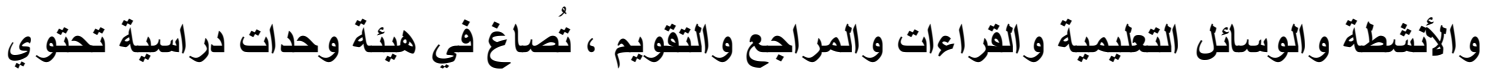
على مجموعة من الدروس المتتابعة تحقى بمجموعها الهدف العام للبرنامج. r. برنامج إعداد التدريب "Retraining Program" :هو برنامج يضم عدة مقررات الهاف منها إعداد الفرد للالتحاق بعمل جديد أو تدريب عمّال على مهارات جديدة تفرض نفسها على العمل نتيجة لتطور ات تكنولوجية . r. البرنامج المكثف "Intensive Program" : هو برنامج يستغرق وقت قـــير نـسبياً ، وبــه. أهداف محددة وهو يقوم على أساس تعليم مهارات معينة في عدد من الساعات ، وقد يستخدم هـــا البرنامج في التعريف بثقافات الثعوب أو تعليم اللغات الأجنبية . 


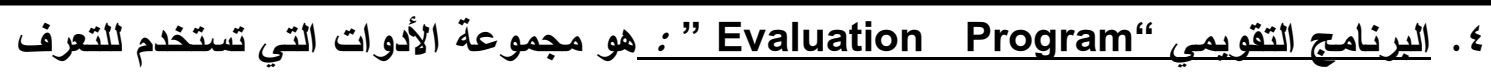

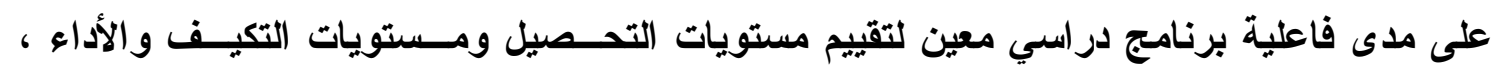

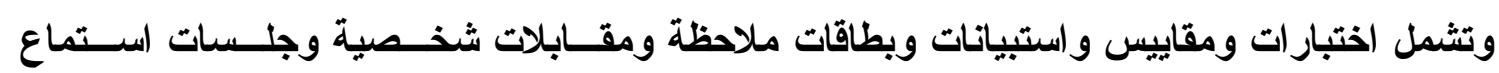
وتقارير فردية وجماعية.

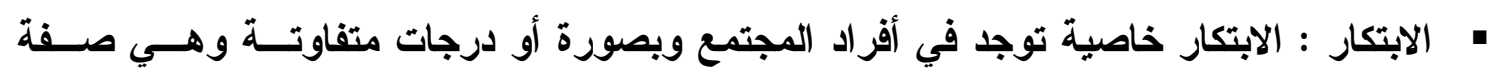
مشتركة بين جميع الطلاب ، حيث أنه مبتكرون بالطبيعة ولايحتاجون إلى مناخ صالح يمكـنـئهم

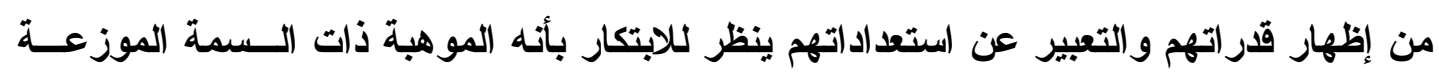

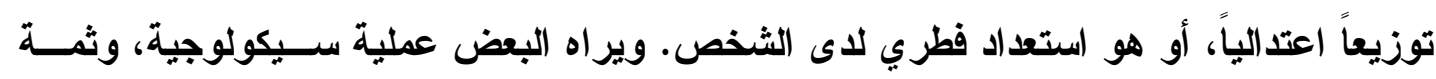
فريق آخر يعتبره أسلوب حياة . م مفاهيم مرتبطة بمفهوم الابتكار : هي مفاهيم تنبثق من الابتكار وتُعتبر مُكملة لهذا المفهـوم أو

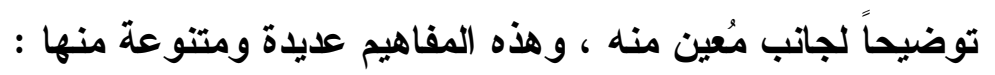

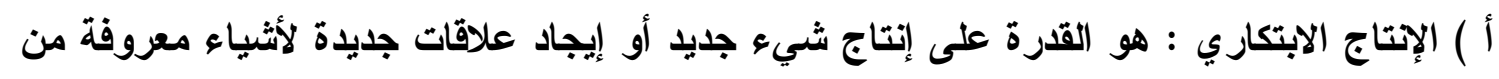

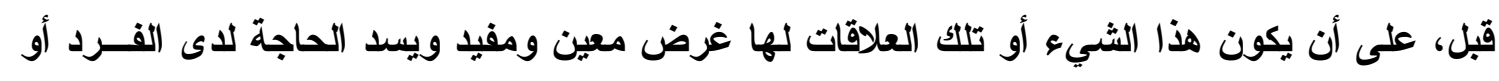

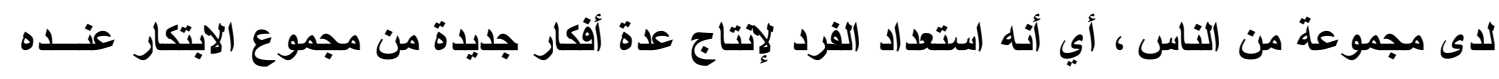

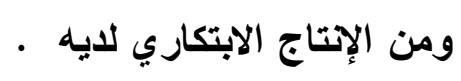
يتأثر الناتج الابتكاري بمجموعة من العوامل وهي العاريه العوامل المعرفية وغير المعرفية مثل عوامل

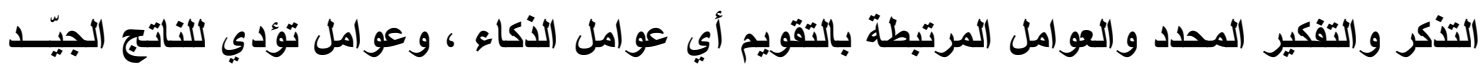

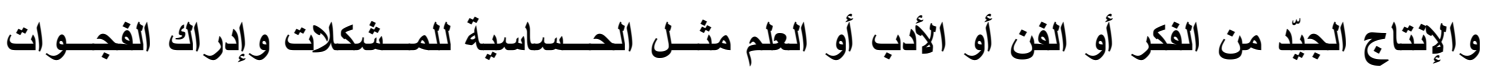

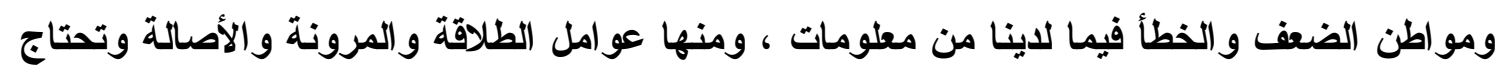

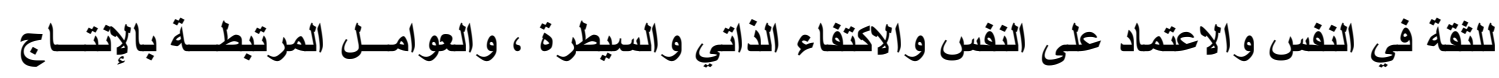

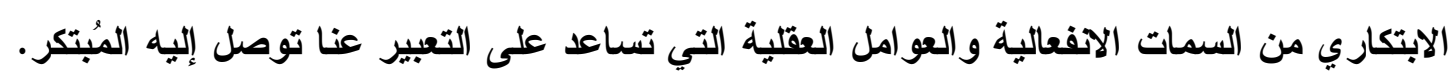

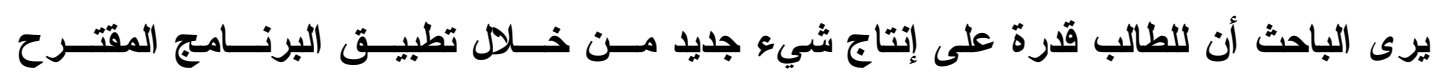

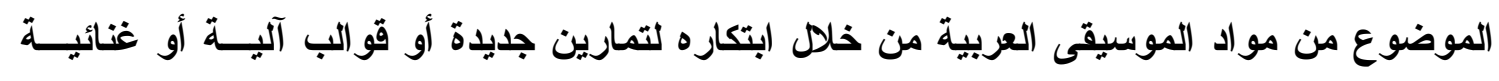

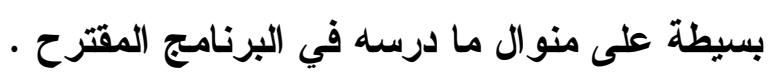

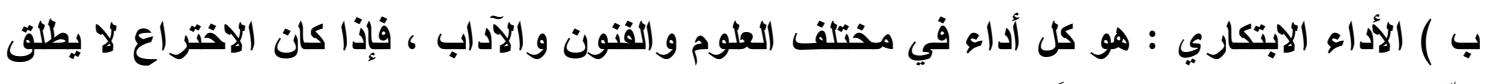

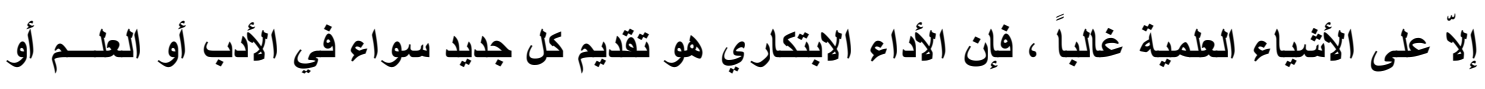

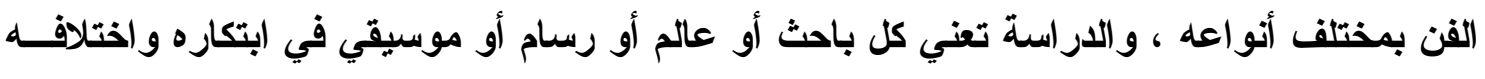

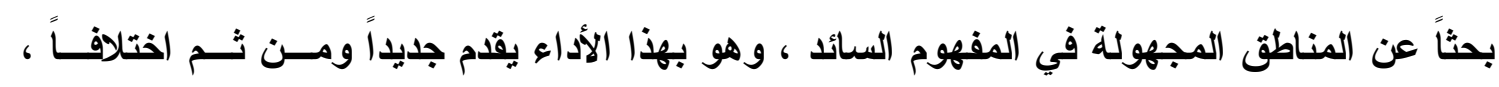

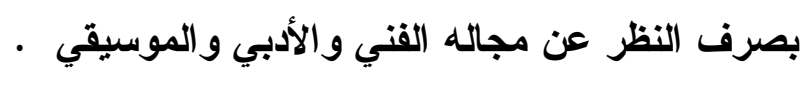

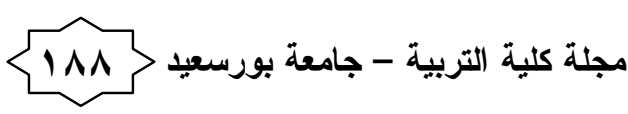
العدد الثاني عثر - يونيو Y I بrم 
يرى الباحث أن للطالب قدرة على أداء الثيء الجديا المبتكر أثناء تطبيقه للبرنامج المقترح الموضوع من مواد الموسيقى العربية .

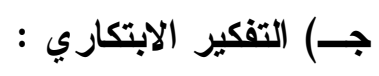
هو التفكير الذي يسعى إلى توليد شيء من جديد ويعتمد على مبادئ مُحتملة ، ويتصل اتــصالاً

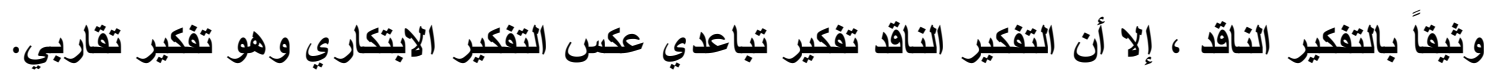

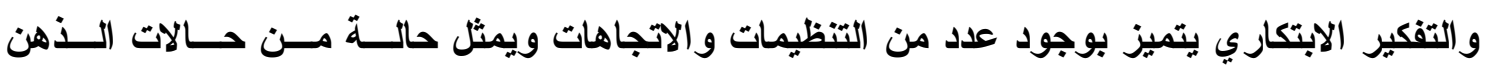

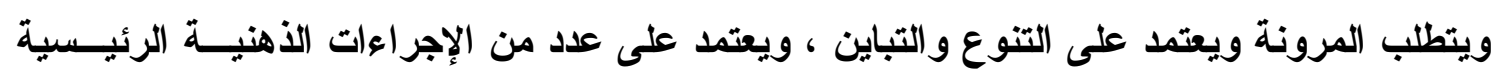

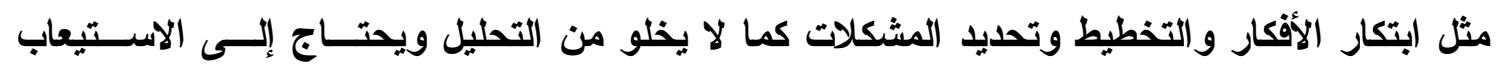

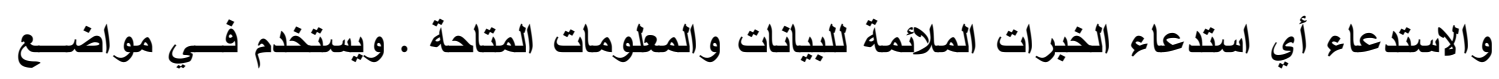

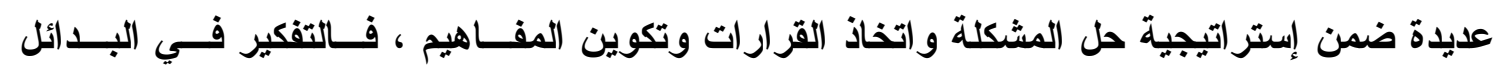

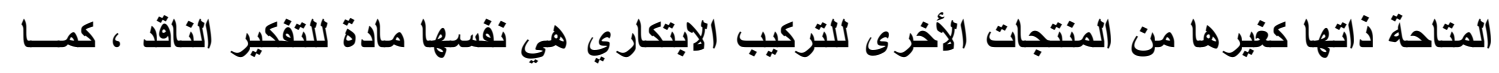
أنه يثمل العادات العقلية التالية: - المشاركة باهتمام في المهام خاصةً عندما لا تظهر الإجابة أو الحلول في الحال.

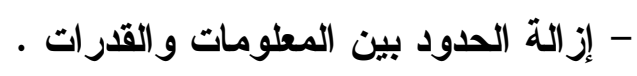

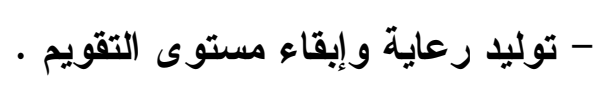

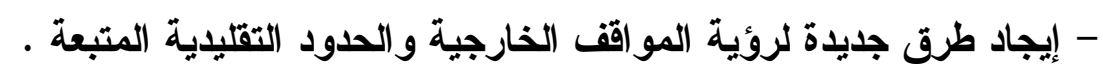

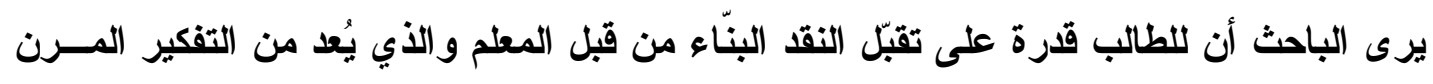

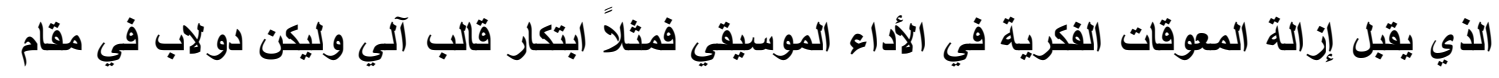

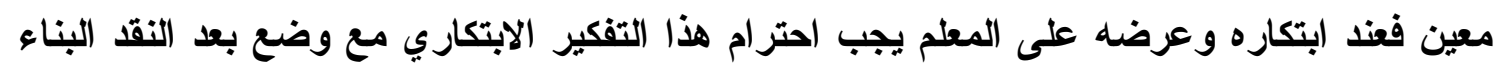

$$
\begin{aligned}
& \text { و الأي لا ينفّر المبتكر. } \\
& \text { • سيكولوجية الطالب المقلّم والمتخصص : } \\
& \text { - الطلاب المتخصصون : }
\end{aligned}
$$

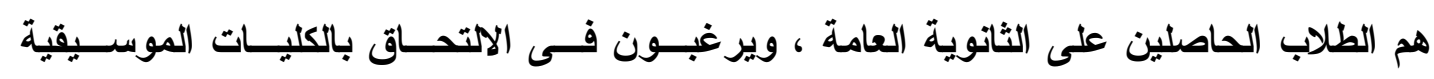

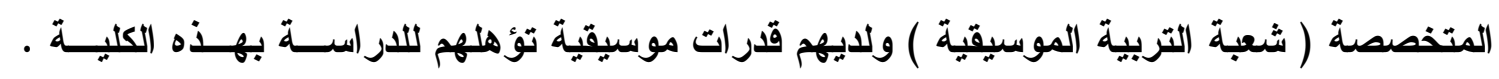

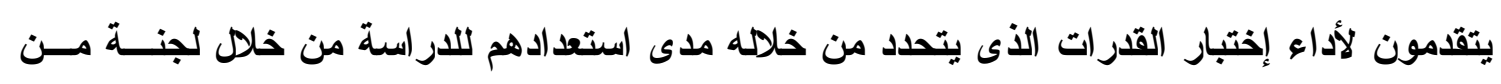

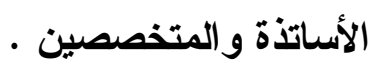

خصائص وسمات الطالب المعلّم و المتخصص موسيقياً :

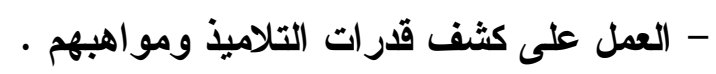

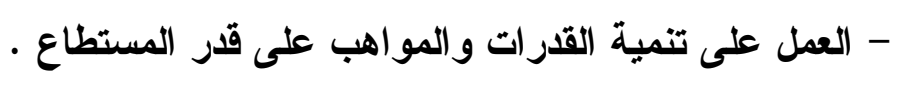

مجلة كلية التربية - جامعة بورسعيد > العدد الثاني عشر - يونيو r ا ب Tم 
- تتبيه السلطات التعليمية إلى الممتازين حتى تتابعهم إلى نهاية التعليم الجامعي وذلك للاستفادة من مو اهبهم . - توفير جو من الدافعية والتشويق وتوفير الوسائل التي يستخدمها لحث التلاميذ علــى الاثــتراك

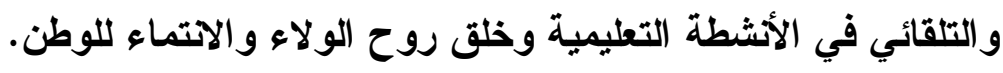

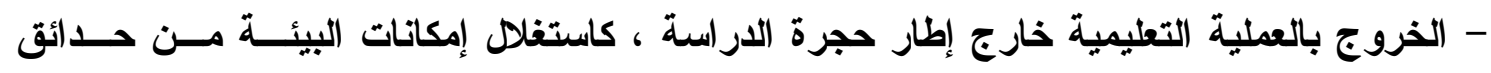

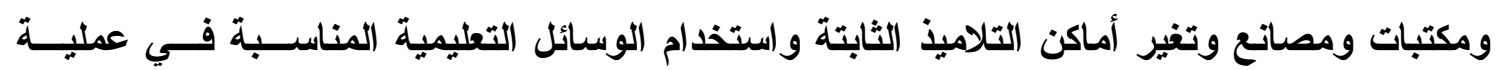
التدريس . - أن يكون معلماً مبتكراً مرناً ، يستطيع أن يبلور أفكار التلاميذ ويساعدهم على نموها ويعمل على

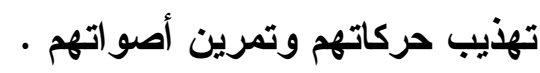
- أن يكون ملماً بأحلث طرق التدريس في مادة التربية الموسيقية، وعلم نفـس الطالـب وأصــول

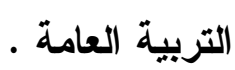
- أن يكون متفهماً لأحدث الطرق الصولفائية من حيث التسلسل في التعليم .

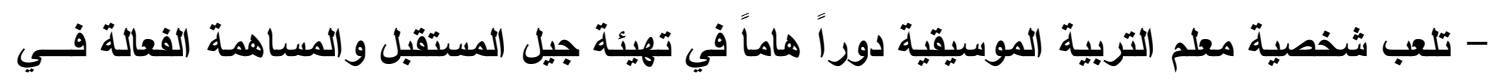
تربية الطلاب عن طريق حصة التربية الموسيقية التي تعتبر المصدر الذي يشيع السعادة والـسرور فئه دئه في نفسية الطالب. • مواد الموسيقى العربية التي تنمي الابتكار : فروع الموسيقى العربية التى يهتم بها البرنامج المقترح لطلاب الفرقة الأولى شعبة التربية الموسيقية بكلية التربية النوعية - جامعة بورسعيد . • مادة تذوق الموسيقى العربية .

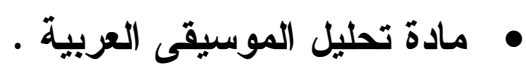

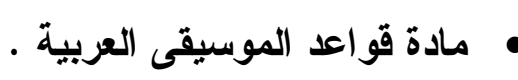

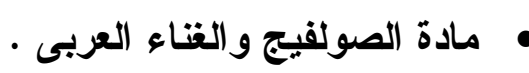
مادة تاريخ الموسيقى العربية .

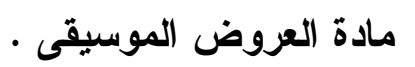
مادة العزف ( عزف الآلات الموسيقية العربية ) . الجزء التحليلي : • منهج البحث : اتبع البحث المنهج الوصفي التحليلي عند أعداد قائمة البنود التدريسسية بمـادة الموسيقي العربية (مقرر الفرقة الأولى) ل 
جدول رقم (1) - جال

يوضح موضوعات الفصل الدراسي الأول وعناوين الحصص وأهم أهداف الموضوع رمع

\begin{tabular}{|c|c|c|c|c|}
\hline أهم أهداف الموضوع & عناوين الحصص & الأسابيع عدد & الموضوع & الموضوع رقم \\
\hline 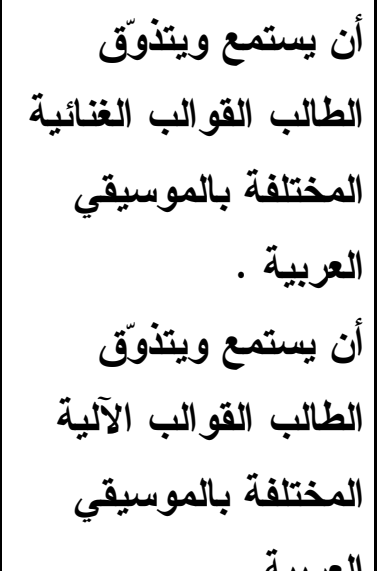 & 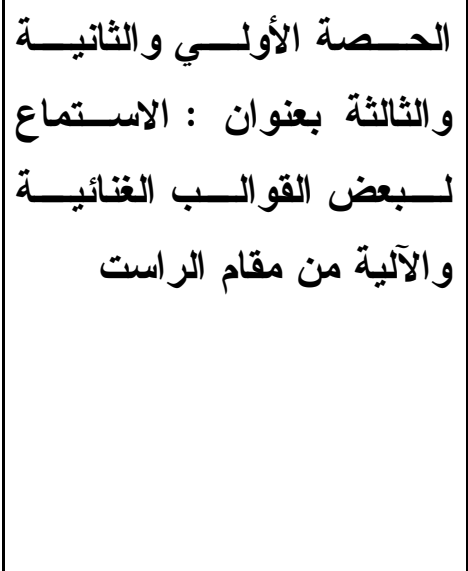 & $\mu$ & 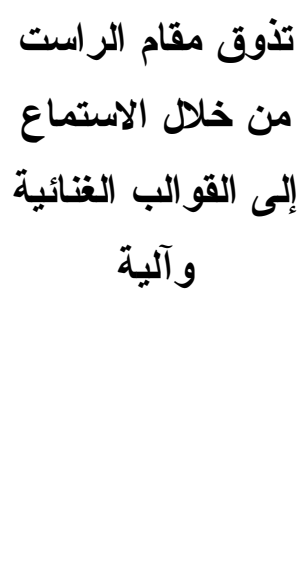 & الأول \\
\hline 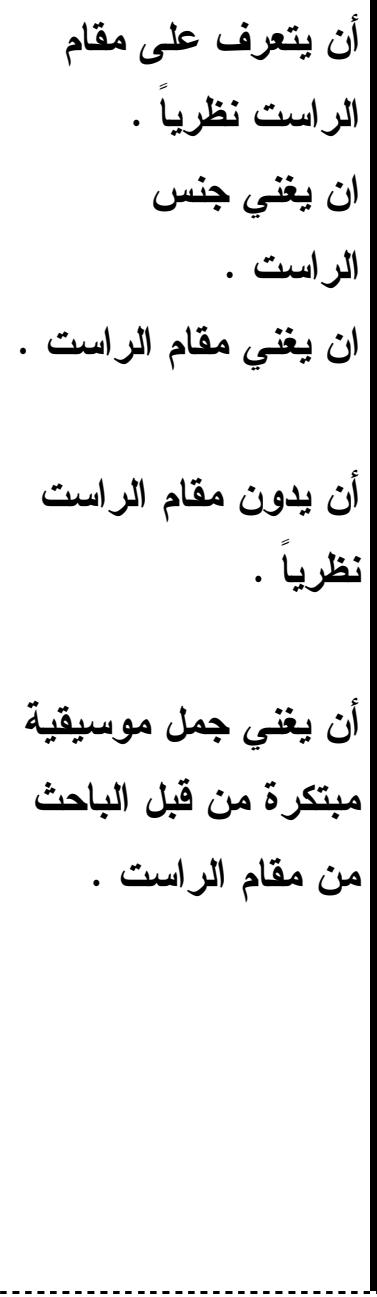 & 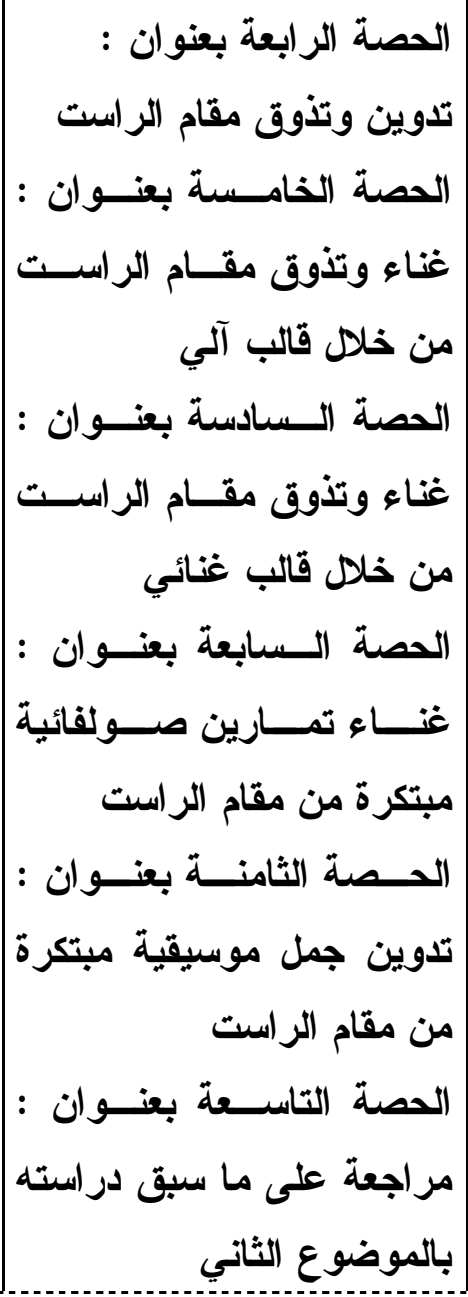 & 7 & 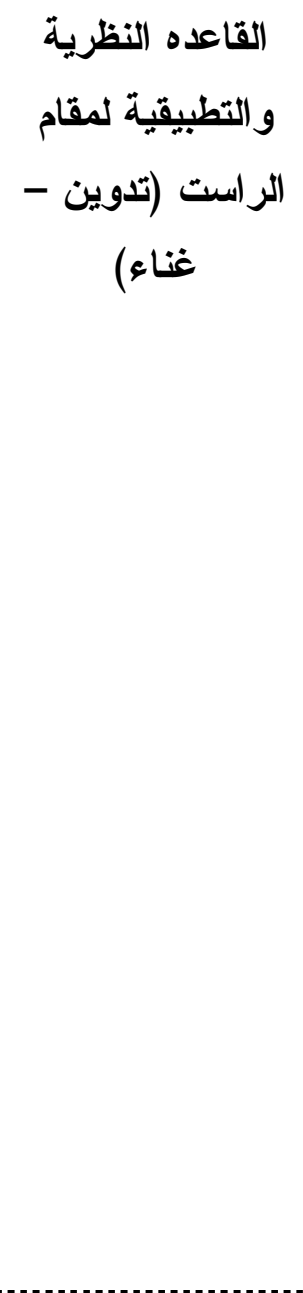 & الثاني \\
\hline
\end{tabular}

مجلة كلية التربية - جامعة بورسعيد >191

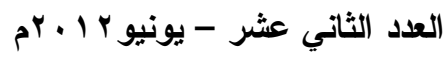




\begin{tabular}{|c|c|c|c|c|}
\hline 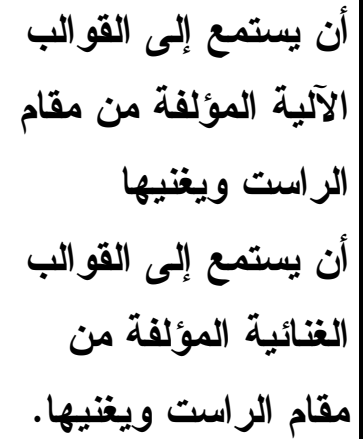 & 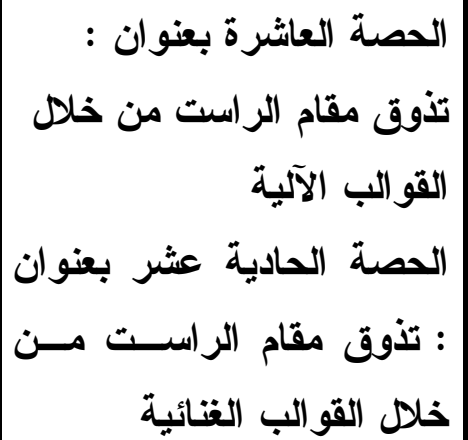 & $r$ & تذوق وغناء مقام & الثالث \\
\hline 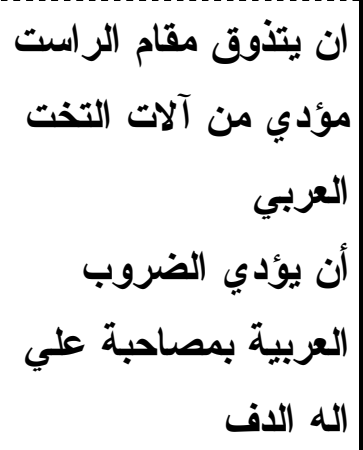 & 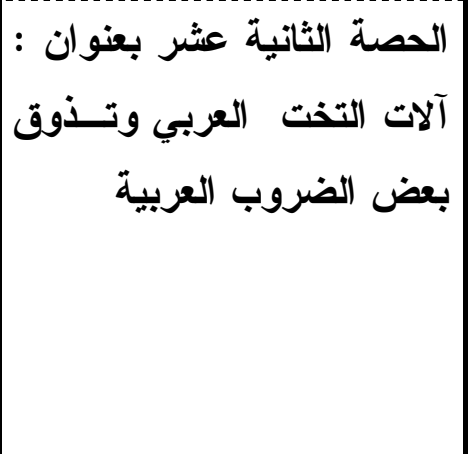 & 1 & آلات التخت العربي & الر ابع \\
\hline 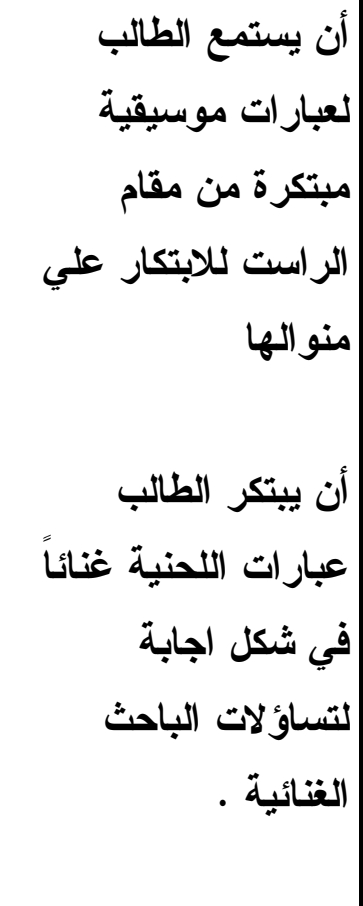 & 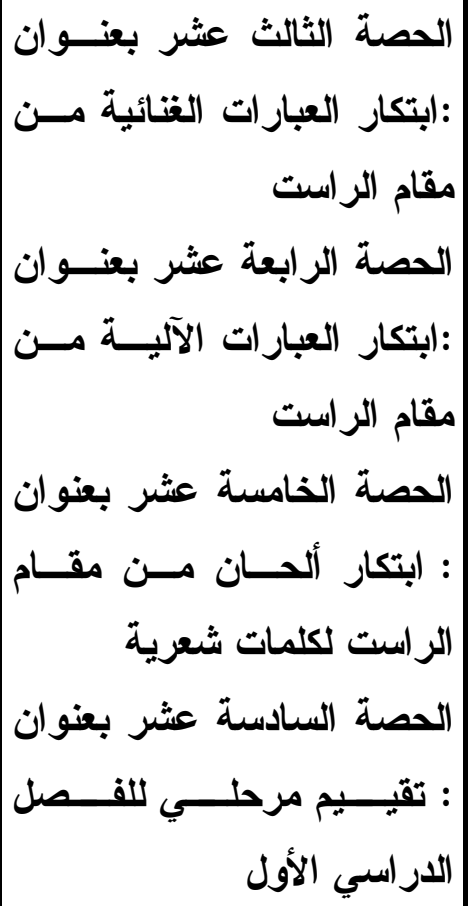 & $\varepsilon$ & الآلية والغمل والعابيات ابتكار & الخامس \\
\hline
\end{tabular}

وفيما يلي عرض لبعض الحصص كنموذج استرشادي لتنفيذ البرنامج المقترح الذي يعـل

$$
\begin{aligned}
& \text { على تنمية الابتكار عند الطلاب في الموسيقى العربية : } \\
& \text { الموضوع الأول بعنوان : الابكار عند الطعان }
\end{aligned}
$$

تذوق مقام الراست من خلال الاستماع لبعض القول الب الفنائية والآلية 
أهداف الموضوع الأول بشكل عام :

1. أن يستمع ويتذوّق الطالب بعض القوالب الغنائية (الطقطوقة-الموشح- الأغنية الثعبية)

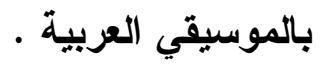

r. أن يستمع ويتذوقّ الطالب بعض القو الب الآلية (الدولاب - اللونجا) بالموسيقي العربية .

r. أن يتعرّت الطالب على نبذه عن بعض أعلام الفناء والتلحين في الموسيقي العربية . • الحصة الأولى بعنوان : الاستماع لبعض القو الب الغنائية والآلية

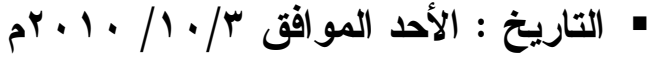

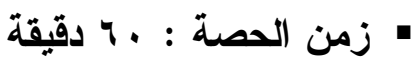

$$
\begin{aligned}
& \text { • أهداف الحصة : } \\
& \text { هدفت هذه الحصة إلى : } \\
& \text { أولاًا : الأهداف المعرفية : }
\end{aligned}
$$

1. أن يستمع ويتذوّق الطالب بعض القو الب الغنائية (الطقطوقة-الموشح) بالموسيقي العربية .

r. أن يستمع ويتذوّق الطالب بعض القوالب الآلية ( الدولاب - اللونجا ) بالموسيقي العربية . r. أن يتعرّف الطالب على نبذه عن بعض أعلام الغتاء والتلحين في الموسيقي العربية .

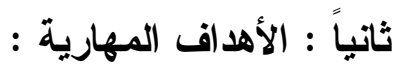

ا ـ أن يفرّق الطالب من خلا السمع بين القو الب ( الغنائية - الآلية ) .

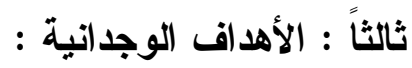

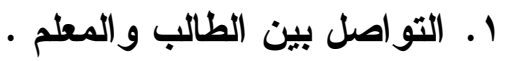

r. ت تنمية الثعور بالاتماء للموسيقى العربية .

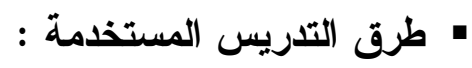

• المحاضرة - المناقثة - البيان العملي .

• الوسائل التعليمية المستخدمة :

• السبورة - العود - جهاز الكمبيوتر الخاص بالباحـث - تـسجيلات صــوتية - مــدونات

موسيقية .

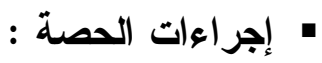

- التمهيذ : يعرض الباحث تقاسيم في مقام الراست لفريد الأطرش ويطلب من الطلاب الاستماع

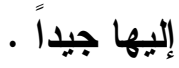

- يعرض المعلم على الطلاب سؤالاً محواه هل هناك صوت بشري أثناء أداء التقاسيم المسموعة ، فيجيب الطلاب بلا ، وهنا يبدأ المعلم في شرح ما هو القالب الآلي عامة . 


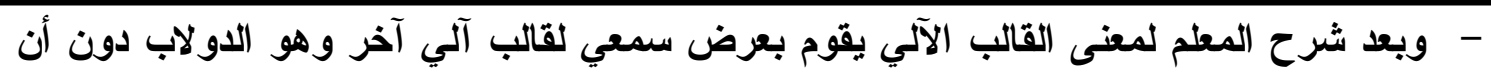

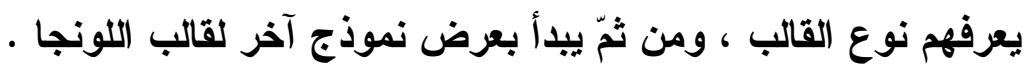

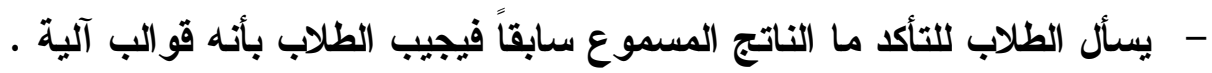
- يعرض الباحث جزء من أغنية " غني لي شوي شوي " لأم كلثوم ويطلب من الطلاب الاستماع

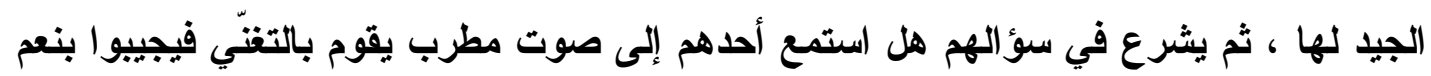

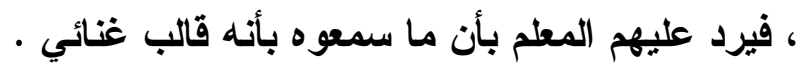
- يعرض المعلم على الطلاب موشع يا شادي الألحان ويكرر المعلم نفس السؤان فال السابق فيجيب

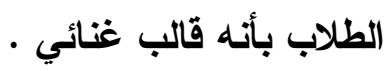
- يبدأ الباحث بالمناقثة مع الطلاب حول ما هو الفرق ما بين ما سمعوه في المرة الأولى والثانية

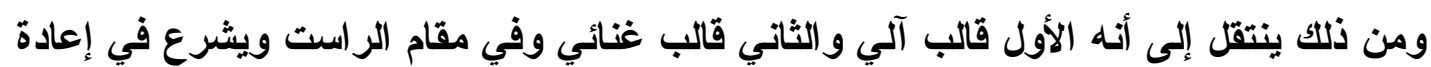

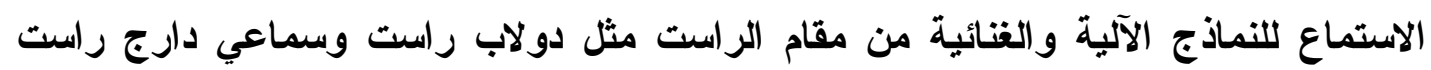

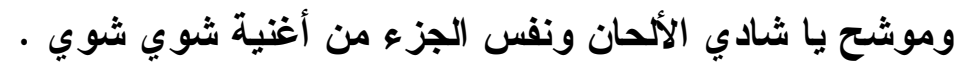

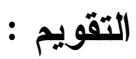

1- استمع جيداً إلى النماذج السابقة من خلا جهاز الكمبيوتر الخاص بك .

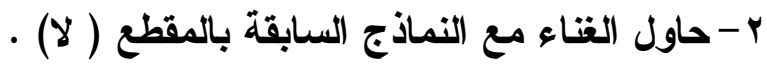

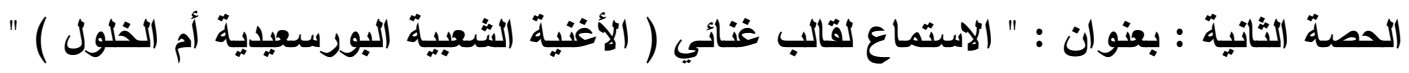

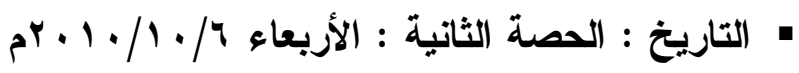
• زمن الحصة : . ب دقيقة . - أهداف الحصة : رمن العهد

- أن يستمع الطالب القالب الغنائي (الأغنية الشعبية) بالموسيقي العربية . • طرق التدريس المستخدمة :

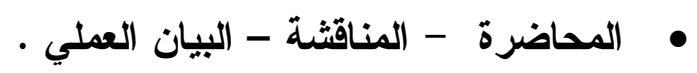
• الوسائل التعليمية المستخدمة : • السبورة - العود - جهاز الكبيوتر الخاص بالباحث - مدونات موسيقية .

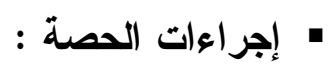

- التمهيا : عرض الباحث على الطلاب نموذج آلي ونموذج غنائي سمعياً من النماذج السابق

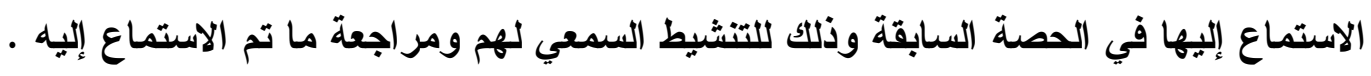
- سأل الباحث الطلاب ما نوعية القالب الأي يستمعون إليه ، ومن ثمّ بدأ الطلاب في الإجابة

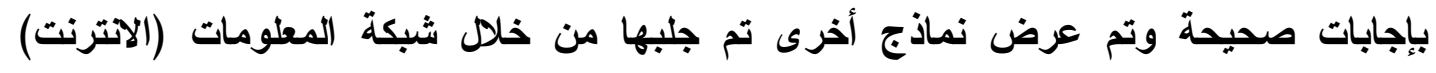

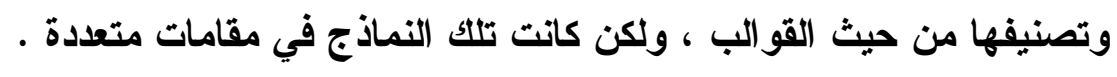




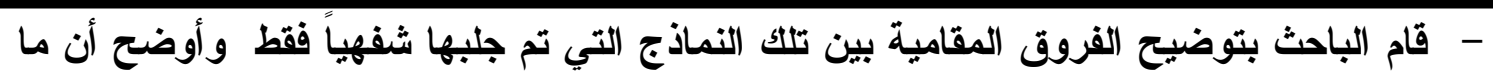
سيتم التركيز عليه هو مقام الراست ، فبدأ الطلاب في سؤاله وما هو مقام الراست، فأجاب الباحث أن هذا موضوع الجلسات القادمة . - عرض الباحث نموذج سمعي آخر وهو أغنية شعبية في مقام الراست ، وقد تخيّر الباحث هذات

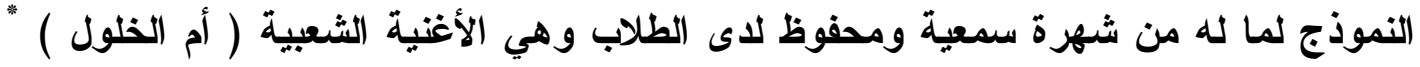
وهي أغنية من وحي البيئة البورسعيدية . كلمات الأغنية الثعبية :

حلوة وعال يا أم الخلول أنا صايدك م الرملة الناعمة على رخصها لكن طعمة آه آه آه يا طعامتك
طازة وعال يا أم الخلول

من غير سنارة يا نعمه

على رخصها لكن طعمة

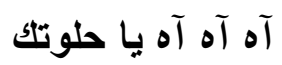

يا حلوتك جنب الفول الطازة

المدونة الموسيقية للأغنية الثعبية :
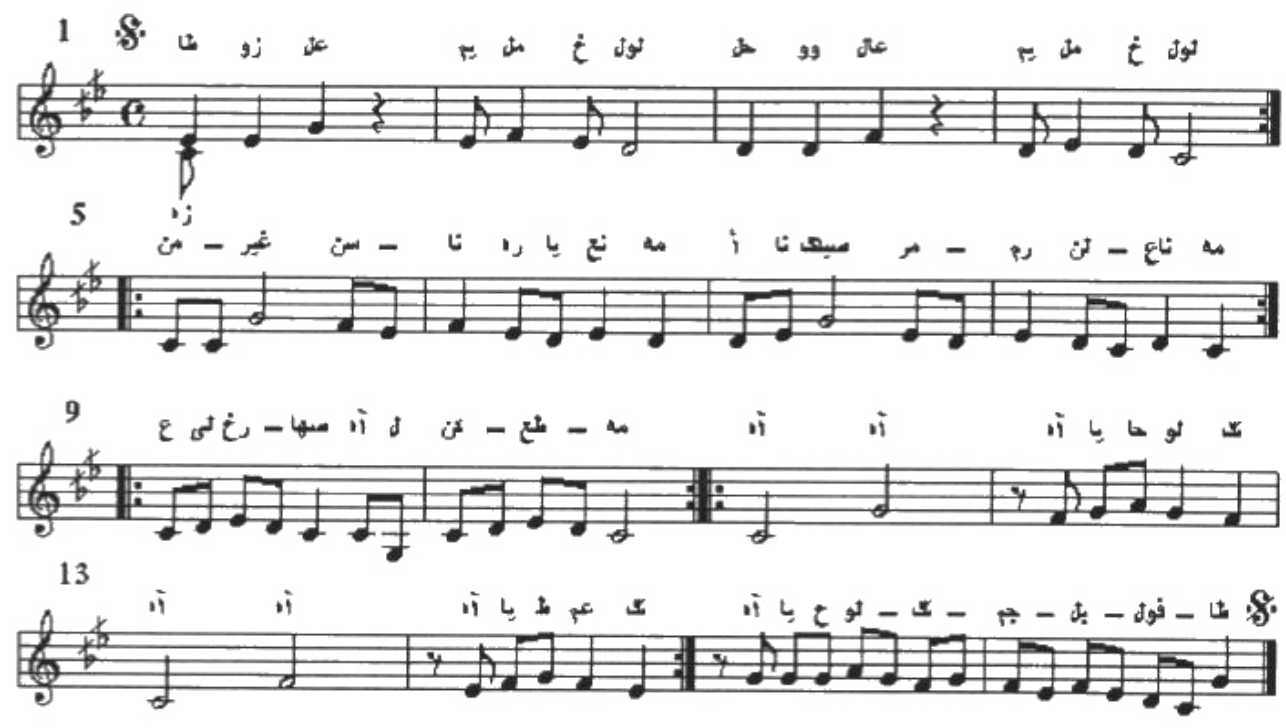

شكل رقم (1)

الأغنية الثعبية أم الخلول

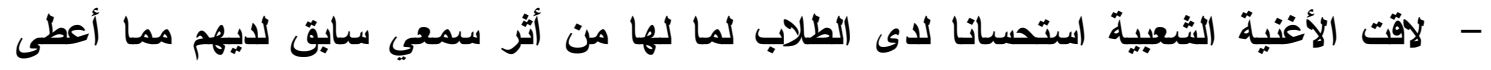

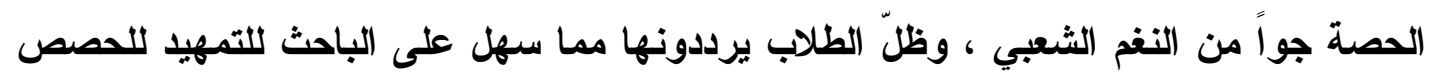

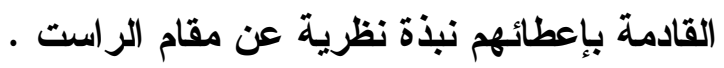

* كامل عيد : " بورسعبد علم ونغم "، ص ، ج ، نقلاً عن : محمود عبد الفتاح محمد محسب : رسالة دكتوراه غير منشورة ،

مرجع سابق ، ص عـ ـ .

مجلة كلية التربية - جامعة بورسعيد

العدد الثاني عشر - يونيو Y I • م 


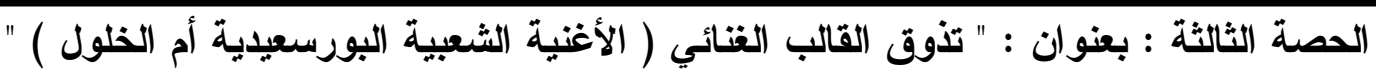

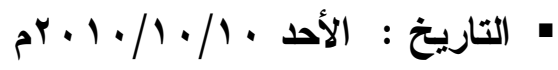

$$
\begin{aligned}
& \text { • زمن الحصة : . . } 1 \text { دقيقة . } \\
& \text { • أهداف الحصة : }
\end{aligned}
$$

- أن يستمع ويتذوق الطالب القالب الغنائي (الأغنية الثعبية) بالموسيقي العربية .

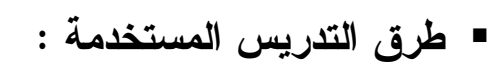

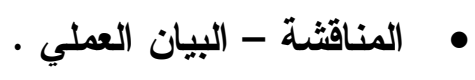

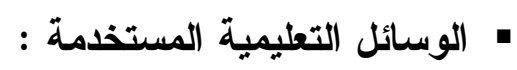

• السبورة - العود - جهاز الكمبيوتر الخاص بالباحسث - تـسجيلات صــوتية - مــدونات

$$
\text { - إجراعات الحصة : موسيقية . }
$$

- عرض الباحث الأغنية الثعبية ( أم الخلول ) " وهي أغنية من وحي البيئة البورسعيدية ، وبعد عرضها عدة مرات من جهاز الكمبيوتر ، تم عرض المدونة الموسيقية للطلاب لإطلاع عليها

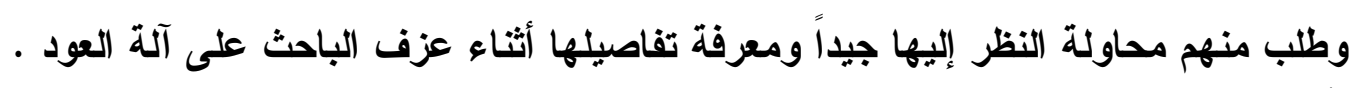

- طُب من جميع الطلاب غناء اللحن بالمقطع (لا)، وقام الباحث بمتابعة غناء الطلاب وتعديل

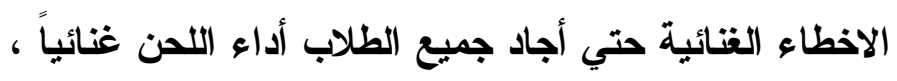

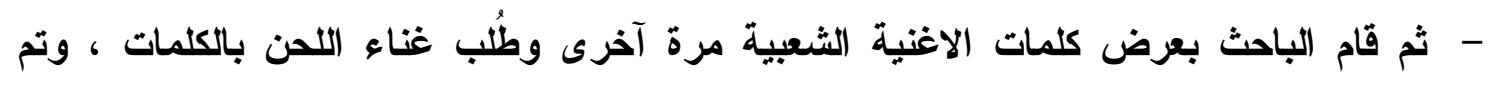

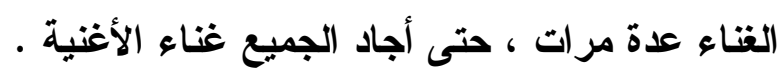

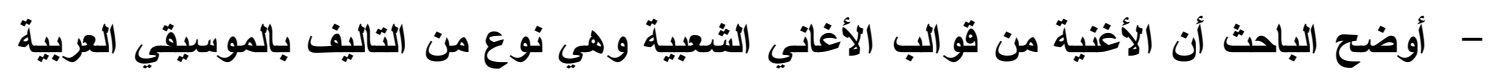

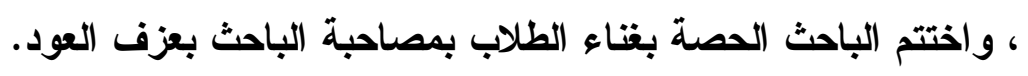

التقويم :

1- استمع جيداً إلى النماذج السابقة من خلال جهاز الكمبيوتر الخاص بك .

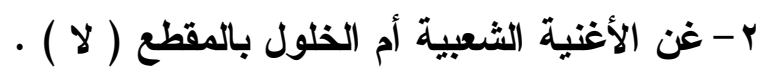

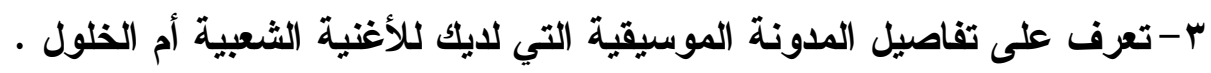
الموضوع الثانى بعنوان : المعيل القاعده النظرية والتطبيقية لمقام الراست (تدوين - غناء)

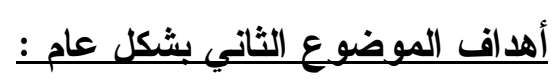
1. أن يستمع إلى القالب الآلي (دولاب) المؤلف من مقام الراست .

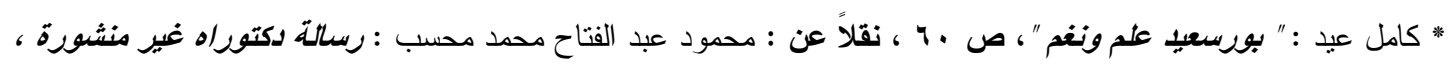

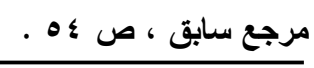

مجلة كلية التربية - جامعة بورسعيد كـ 199

العدد الثاني عثر - يونيو r ا بrم 
r. أن يستمع إلى القالب الغنائي (طقطوقة) المؤلف من مقام الراست .

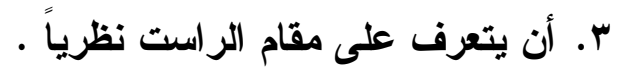
ـ. أن يتعرف على مواصفات تكوين الجمله الموسيقية نظرياً.

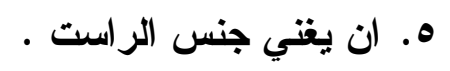

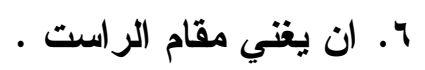

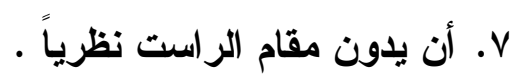

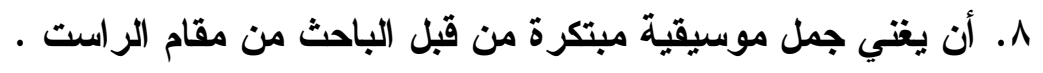

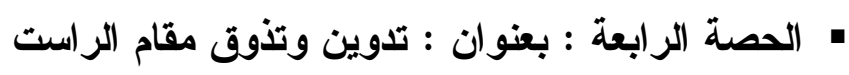

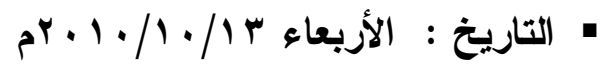

$$
\begin{aligned}
& \text { • زمن الحصة : . . }
\end{aligned}
$$

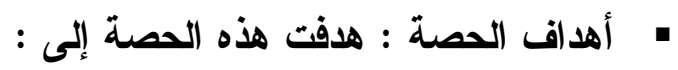

أولاً : الأهداف المعرفية:

$$
\text { 1. أن يستمع إلى جنس الراست (أصل - فرع) . }
$$

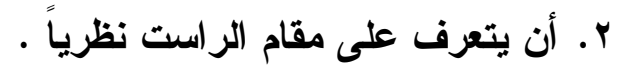

r. أن يتعرف على مواصفات تكوين الجمله الموسيقية نظرياً.

$$
\text { ثانياً : الأهداف المهارية : ان بترف }
$$

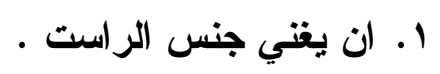

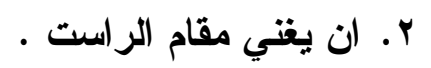

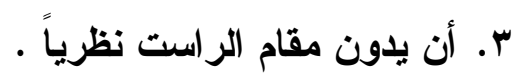

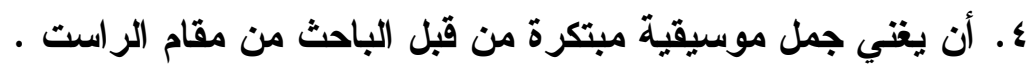

$$
\begin{aligned}
& \text { • طرق التريس المستخدمة : } \\
& \text { • المحاضرة - المناقثة - البيان العملي ل } \\
& \text { • الوسائل التعليمية المستخدمة : }
\end{aligned}
$$

• السبورة - العود - جهاز الكمبيوتز الخاص بالباحسث - تـسجيلات صــوتية - مــدونات

$$
\text { • موسيقية . إجراءات الحصة : }
$$

- التمهيد : من خلا عزف الباحث لتقاسيم من مقام الراست بدون تحويلات داخلية .

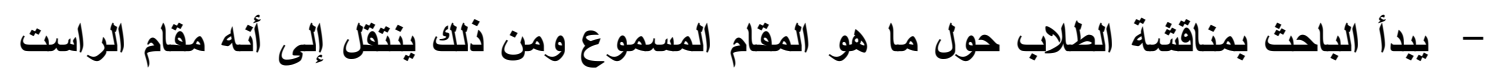

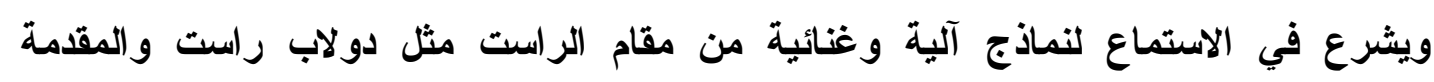

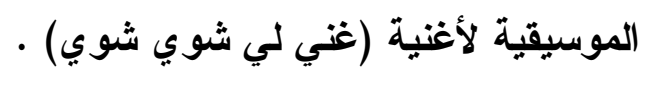


- مناقشة الطلاب حول التدوين الموسيقي وأهميته وعرض تدوين جنس راست.

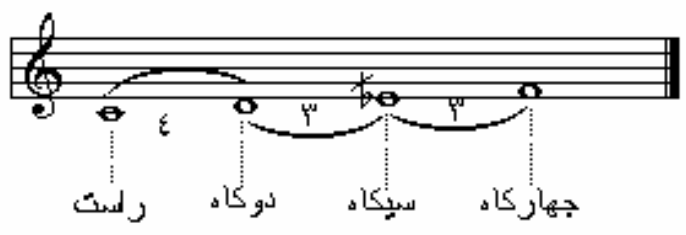

شكل رقم (r)

جنس الأصل لمقام الراست جنس راست على درجة الر است

- بعد عرض وشرح الباحث لجنس الأصل لمقام الراست تم الاستماع إليه من خلا آلة العود صعوداً وهبوطاً ، وقدم الباحث تقسيمه بسيطة في هذا الجنس.

- - طلب الباحث من الطلاب غناء جنس الراست بالمقطع (لا) حتى تم إجادة غنائه . - بأ الباحث في عرض جنس الفرع لمقام الراست وهو جنس راست على درجة النوا ، وشرح الباحث للطلاب أن أبعاد جنس الفرع مطابقة تماماً لأبعاد جنس الأصل ولكن الاختلاف في درجة

البداية فقط ـ ومن ثمّ عرض عليهم تدوين جنس الفرع .

$$
\text { هنس الترن }
$$

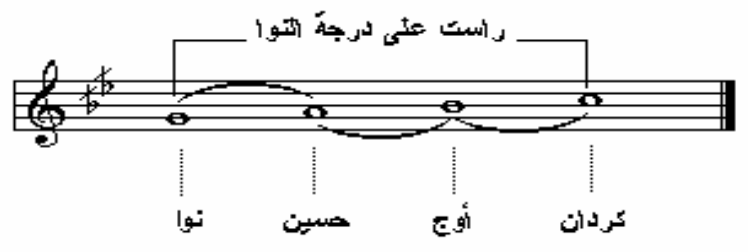

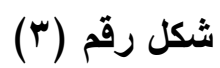

جنس الفرع لمقام الر است جنس راست على درجة النوا

- بعد عرض وشرح الباحث لجنس الفرع لمقام الراست تم الاستماع إليه من خلا آلة العود صعوداً وهبوطاً ، وقدم الباحث تقسيمه بسيطة في هذا الجنس. - تم عرض تدوين مقام الر است كاملاً كالتالي :

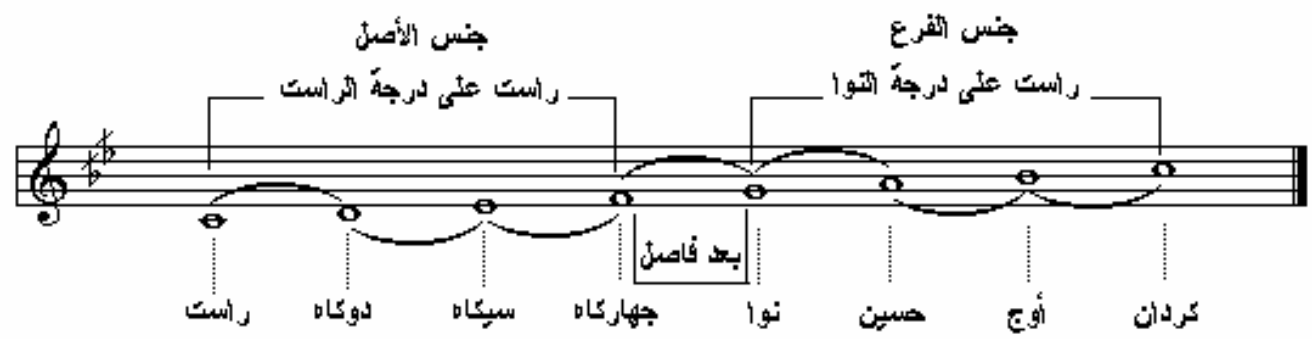

شكل رقم (ع) - مقاد

مقــــــــام الراســــــت 
- - طلب الباحث متابعة آلة العود بالغتاء في المقام بالمقطع (لا) مرة ثم بتسمية النغمات مرة أخرى

$$
\text { حتى تم الإجادة . }
$$

- غناء جمل موسيقية في جنس الراست (سؤال وجواب ومحاولة اثرالك الطلاب في ابتكار

$$
\text { (العبار ات في صيغة إجابة) }
$$

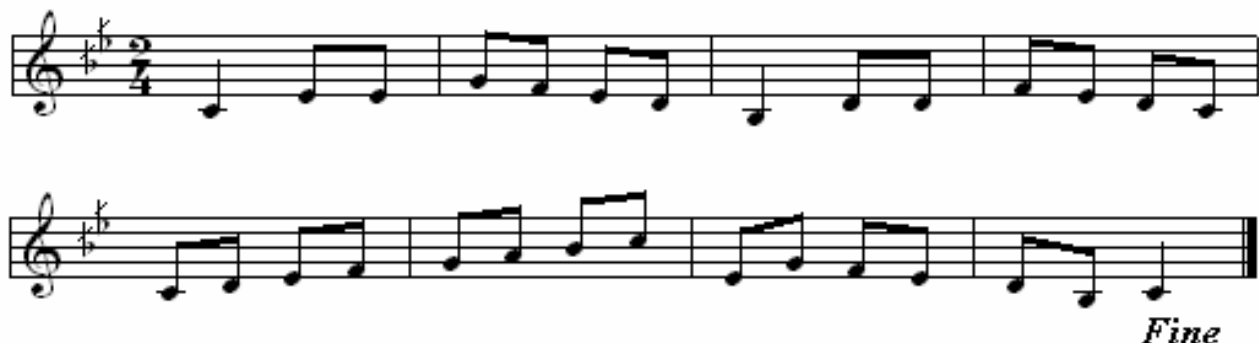

شكل رقم (0)

نموذج معزوف من مقام الر است مبتكر من قبل الباحث

- بعد محاولة غناء الطلاب للجملة الموسيقية السابقة وترديدها عدة مرات وضح للباحث ركوز مقام الراست سمعياً لايهم مما أتاح له فرصة أن يطلب منهم ابتكار جملة موسيقية أخرى في نفس المقام بعد إعطائهم جملة من مازورتين على هيئة سؤال ، وكاتت الجملة كالتالي :

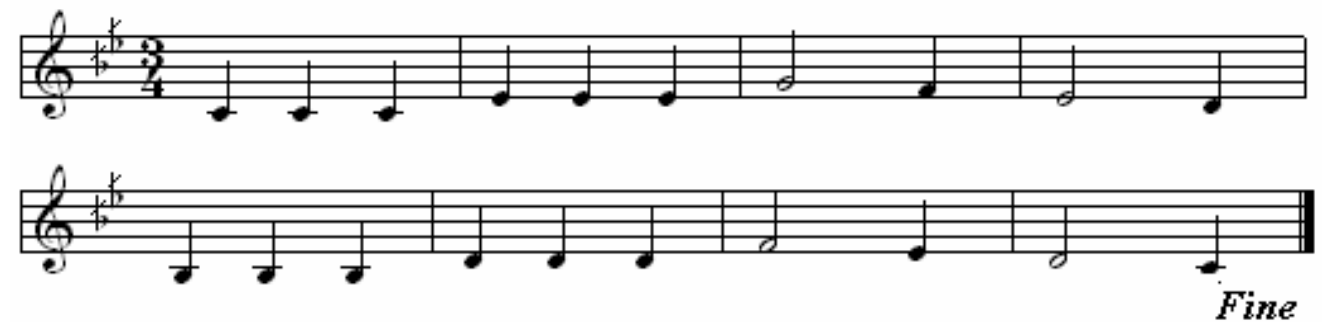

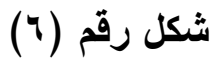

نموذج مبتكر من أحد الطلاب من مقام الر است

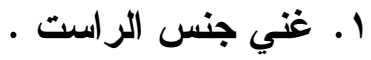

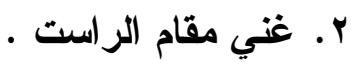

r. دون مقام الر است نظرياً .

ـ. غني جمل موسيقية من مقام الر است في صيغة جواب على سؤال الباحث.

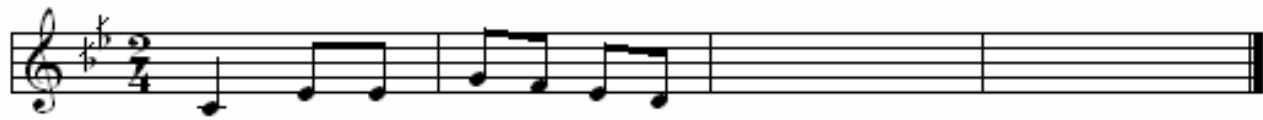

(v) شكل رقم

جملة على هيئة سؤال مبتكرة من قبل الباحث في مقام الراست 


\section{نتائج البحث :}

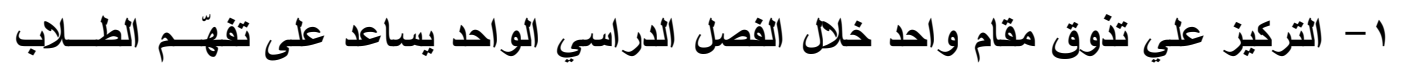

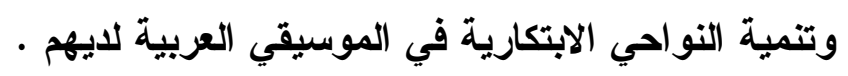

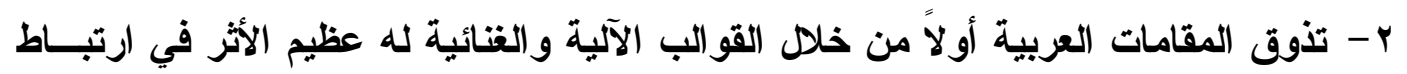

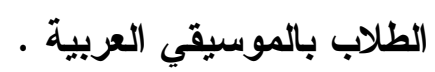

r- تقيم الجوانب النظرية للمقامات العربية في مرحلة تلي تذوق المقام غنائياً و آلياً يسساعد

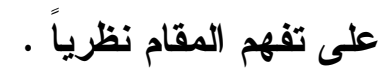

ع - تنوع الأنشطة التدريسية بالحصة من استماع وغناء وابتكار يساعد على عـدم انبعـاث

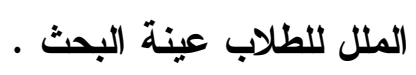

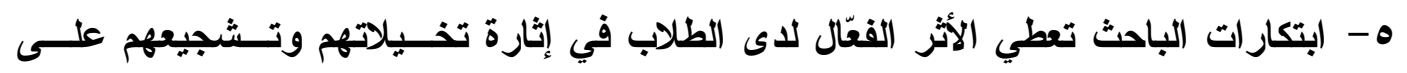

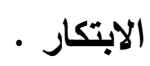

צ- تمييز الطلاب في الابتكار الغنائي عنه في الابتكار الآلكي ويرجع ذلك لقلة التكنيك العزفي

$$
\text { للطلاب }
$$

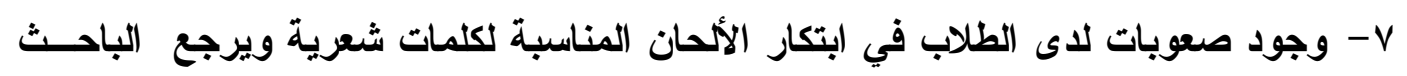

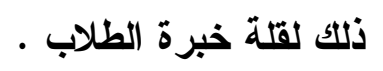

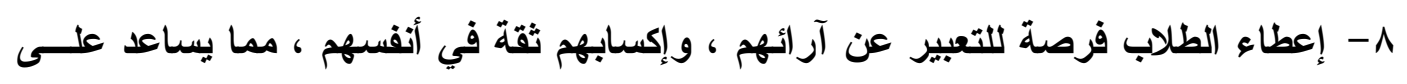

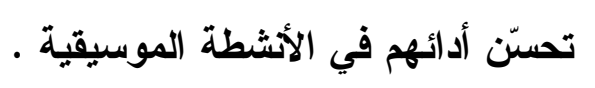

9 - مشاركة الطلاب مع بعضهم البعض في عمل داخل الفصل الدراسي يساعد على نثر روح

$$
\text { توصيات البحث: يوصي الباحث بما يلي : التعاون والمنافسة . }
$$

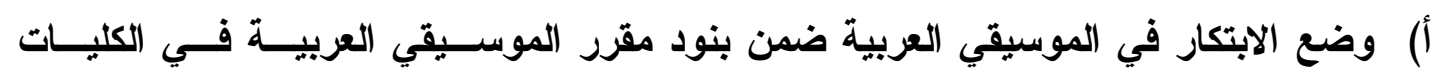

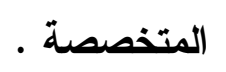

ب) الاهتمام بطلاب الفرقة الأولى وإعدادهم فنياً حيث أنهم نواه معلمي الغد .

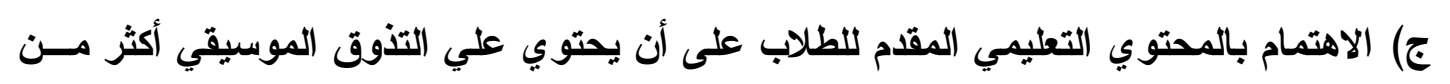

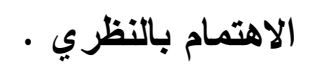

د) تعديل الخطط الدراسية حتى تثثمل التعليم الموسيقي بنسب أكبر من المــو اد التربويــة فــي

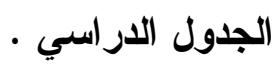

م) عمل دورات تدريبية لمعلمي التربية الموسيقية تهاف لتنمية القدرة الابتكارية في الموسيقي

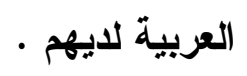

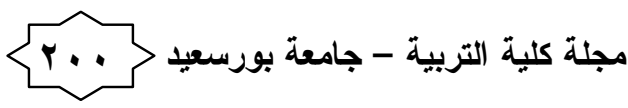

$$
\text { العدد الثاني عشر - يونيو r I بr }
$$


المراجع

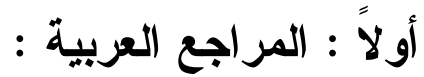

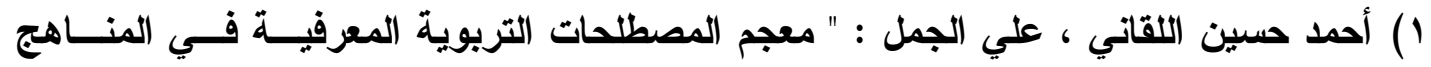

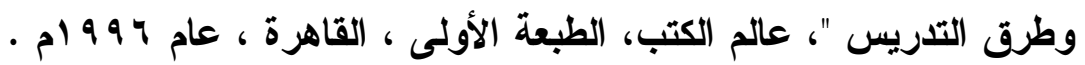

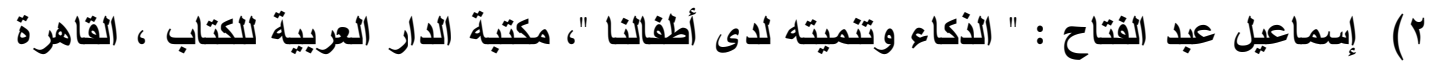

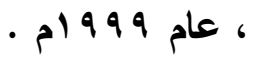

r) آمال حسين خليل : " الإبداع واستر اتيجيات تلريس التربية الموسيقية "، الإسـكندرية ، دار

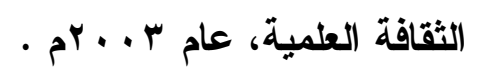

؛) تهاني محرم حسن محرم " برنامج مقترح لتنمية الإبتكارية في مادة الصولفيج لطلاب كليـة

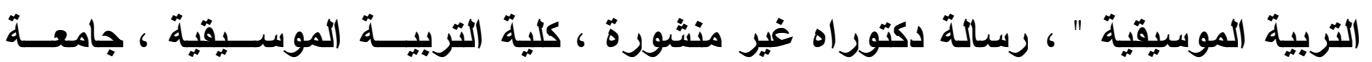

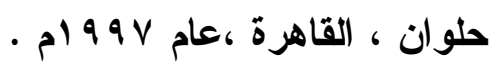

•) حسين عبد الباري عصر : " التفكير مهاراته واستراتيجيات تدريسه "، مركــز الإســندرية

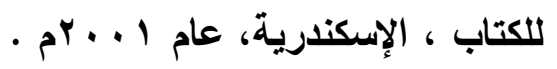

7) خالد عبد الرازق السيد : " سيكولوجية الأطفال ذوي الاحتياجات الخاصة "، مركز الإسكندرية

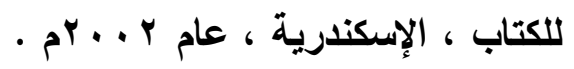

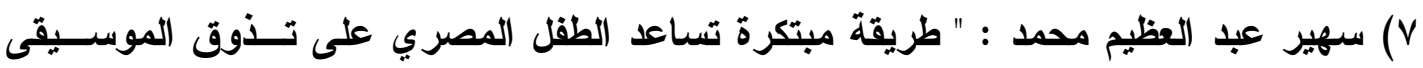

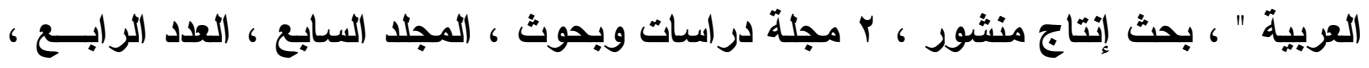
أكتوبر ، جامعة حلوان القاهرة ، عام ع 91 ام .

^) سهير عبد العظيم محمد : " طريقة مقترحة للتدريس الصولفيج العربـي " ، بحــث إنتـاج

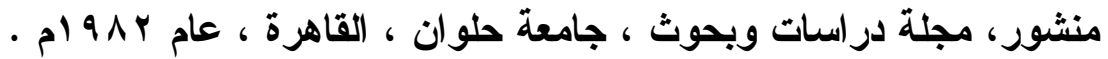

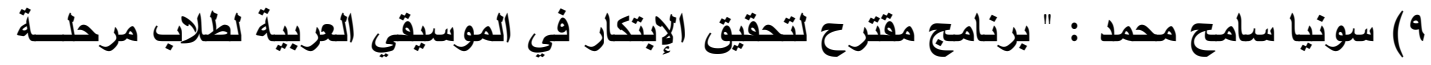
البكا لوريوس بكلية التربية النوعية " ، رسالة دكتوراة غير منشورة ، كلية التربية النوعية

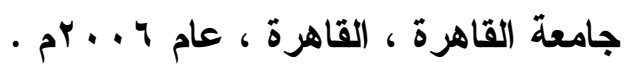

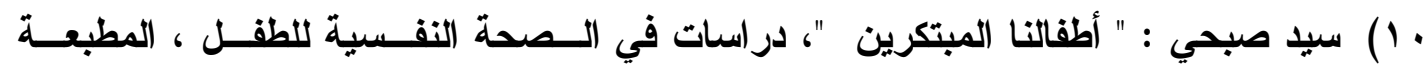

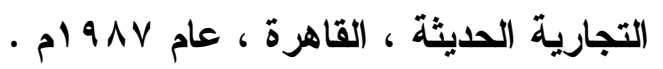

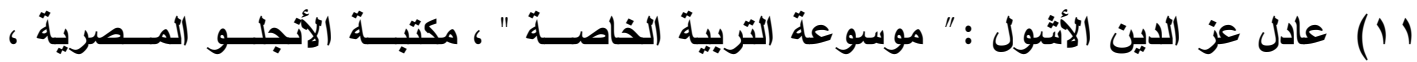

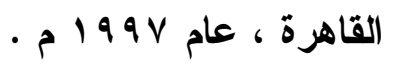

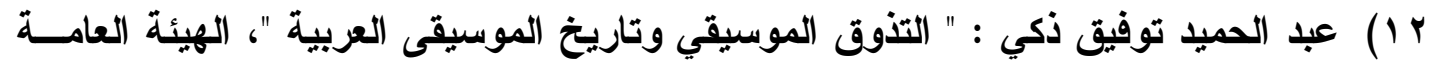

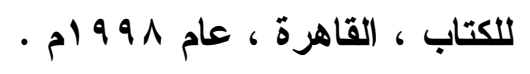

مجلة كلية التربية - جامعة بورسعيد >

$$
\text { العدد الثاتي عشر - يونيو r I بr }
$$


بr 1) عزيز الثوان : " الموسيقي تعبير نغمي ومنطق" ، الهيئة المصرية العامة للكتاب ، مكتبة

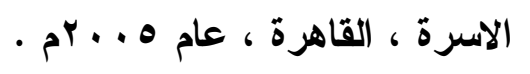

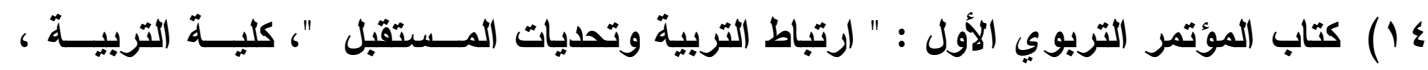

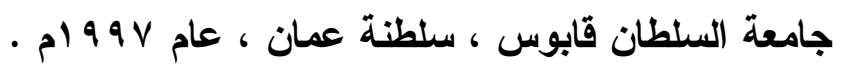

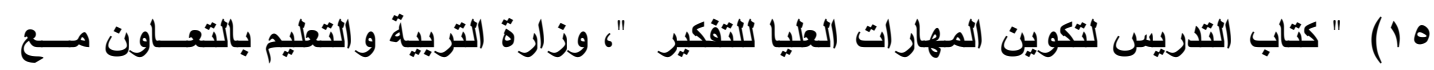

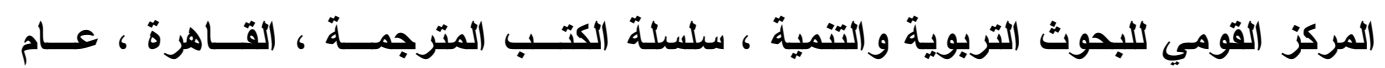
- م 1990 1.

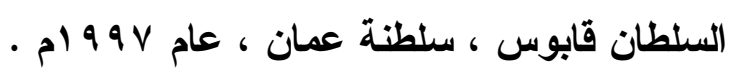

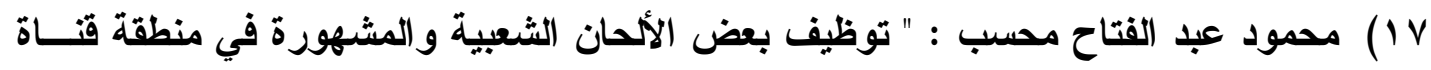

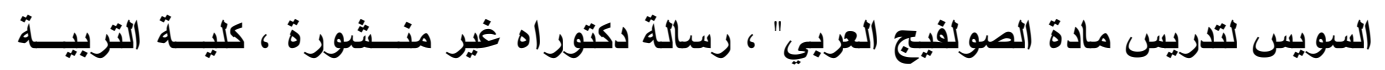

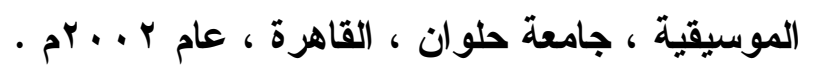
ثانياً : المراجع الأجنبية :

18) Larousse Selection : "Nouveau Dictionaries Encyclopedia ", Vol.1, Selection Du Reader's Digest, Paris, 1968.

19) Webster A. Meryian: “Webster's Dictionary”, Massachusetts, U. S. 1976. 